\title{
HOMOEROTISMO E PERFORMANCES: AS REPRESENTAÇÕES DOS CORPOS E DAS RELAÇÕES HUMANAS NA ANTIGUIDADE ROMANA A PARTIR DAS PINTURAS DE POMPEIA
}

Pérola de Paula Sanfelice ${ }^{1}$

\begin{abstract}
Resumo
Os estudos da antiguidade, dentre as disciplinas acadêmicas, são aqueles considerados como o mais conservador, no entanto, por meio da interdisciplinaridade, sobretudo a partir do diálogo com a Arqueologia, esta área de conhecimento tem conseguido alcançar perspectivas mais críticas, sobretudo, em pesquisas sobre o amor e a sexualidade. Nesse trabalho, dialogo, em grande parte, com as pesquisas produzidas pelo classicista Pedro Paulo Funari, que, por sua vez, inspirou diversos pesquisadores brasileiros a romper com os modelos normativos, questionando antigos conceitos e valores patriarcais a fim de trazer à tona uma antiguidade clássica mais libertária. Deste modo, apresento algumas discussões a respeito da sexualidade e do gênero na Antiguidade romana, incialmente, um debate de natureza teórica, e, num segundo momento trago algumas pinturas de relações eróticas com práticas diversificadas, com ênfase particular às relações homoeróticas, encontradas em uma terma suburbana do sítio arqueológico de Pompeia, a fim de evidenciar as diferentes maneiras que os indivíduos interpelavam as normas, bem como questionar as noções de pornográfico e trabalhar as relações das imagens com os seus contextos.
\end{abstract}

\section{Palavras-chave}

Antiguidade Clássica; sexualidade; homoerotismo; pinturas romanas; termas romanas; Pompeia.

1 Professora Doutora, Pontifícia Universidade Católica do Paraná, Curitiba, Brasil. email: perolasanfelice@gmail.com 


\begin{abstract}
Among the academic subjects, Ancient Studies are those considered the most conservative. However, through interdisciplinarity (particularly through the dialogue with Archaeology), this field of study has managed to reach more critical perspectives, mainly in researches on love and sexuality. This work keeps a dialogue with the research carried out by the classicist Pedro Paulo Funari, who, in turn, has inspired many Brazilian researchers to break up the normative models, questioning old concepts and patriarchal values to give rise to a more libertarian classical antiquity. After presenting a discussion on gender and sexuality in Ancient Rome, a theoretical debate is proposed. Later on, some paintings of erotic relationships, showing diversified practices (particularly emphasizing homoerotic relationships), found in a suburban bath in the Archaeological Site of Pompeii, are presented to evince how differently individuals interpellated norms, to question the definition of pornography and to deal with the relationships between the images and their contexts.
\end{abstract}

\title{
Keywords
}

Classical Antiquity; sexuality; Roman Paintings; Roman Baths and Pompeii. 


\section{Introdução}

Et quae tanta fuit Romam tibi causa uidendi? Libertas, quae, sera, tamen respexit inertem.

E qual o motivo tão grande de visitares Roma? A Liberdade, que, embora tardia, contudo olhou favoravelmente para mim, inerte (Bucólica I, vv. 27-28). Estas famosas palavras da primeira Bucólica virgiliana, inspiradoras para os inconfidentes mineiros, também foi a citação selecionada por Pedro Paulo Funari para refletir sobre o potencial da História Antiga na formação de um pensamento crítico no presente. Contudo, para esse autor, o passado foi tanto inspirador da luta pela igualdade e liberdade, como, mais comumente, serviu para justificar o status quo patriarcal e opressivo (2004: 17). A respeito dessa segunda vertente, o historiador Glaydson José da Silva (2007) apresenta uma interessante discussão sobre como a memória acerca do mundo antigo esteve profundamente vinculada às questões de identidades nacionais, chamando a atenção para o fato de que, durante o período compreendido pela Modernidade, muito se recuperou do passado Clássico, a fim de justificar uma suposta herança cultural atribuída ao Ocidente. Se por um lado a Grécia antiga serviu como um modelo de civilização e de democracia, por outro, buscou-se ressaltar no passado romano seu imperialismo, sua força bélica, sua literatura, suas construções e sua arte. Ou seja, o uso de uma Antiguidade clássica opressora é, portanto, muito anterior, mas muito mais persistente, do que as mais conhecidas e criticadas apropriações fascistas de meados do século $X X^{2}$.

Dentre tantos "usos do passado", existe um aspecto muito particular que gostaria de ressaltar - quando se recorreu a Antiguidade, em busca de identidades gloriosas, excluiu-se uma série de interpretações e temas de estudo, entre eles a sexualidade. Assim, o tema da sexualidade, além de um tabu social, foi controlado por diferentes formas de políticas e, também, entendido como algo secundário no campo das Ciências Humanas. Somente a partir das últimas duas décadas, as sociedades ocidentais passaram pela contestação sistemática dos valores normativos e homogêneos propugnados pela ciência. Fruto de discussões filosóficas de meados de 1960, que

\footnotetext{
2 Cf. (Silva, Garraffoni, Funari, Gralha, \& Rufino, 2017), nesta obra, uma série de pesquisadores brasileiros repensam os conceitos e modelos interpretativos acerca do mundo antigo, cunhados nos séculos XVIII, XIX e XX, propondo uma reflexão acerca do papel do passado nos jogos de estratégias e afirmações identitárias do presente. Em especial, há um capítulo em que abordo juntamente com a pesquisadora Renata Senna Garrafonni, a construção da doutrina fascista pautada no culto da romanidade, em que se mesclam a História Romana clássica com a História Nacional Italiana a partir das escavações do sítio arqueológico de Pompeia, cf. (Garraffoni \& Sanfelice, 2017).
} 
estimularam uma revisão de conceitos e valores tradicionais, dentre eles o regime de verdades instituído sobre as relações de gênero (Feitosa \& Rago, 2008). Nesta perspectiva, as teorias de vertentes feministas pensaram a sexualidade como produto de diferentes tecnologias e práticas institucionalizadas. Entendeu-se que tanto a sexualidade quanto o gênero não poderiam ser propriedades dos corpos, como também não seriam inatos aos seres humanos, mas sim um conjunto de efeitos produzidos nestes corpos, comportamentos e relações sociais, por meio de uma complexa tecnologia política e cultural (Lauretis, 1994). O gênero passou a ser compreendido como relação primordialmente política que ocorre num campo discursivo e histórico de relações de poder (Scott, 1995).

Nesse sentido, me parece interessante recuperar as propostas de Judith Butler (2010), acredito que os pressupostos desta filósofa nos fornecerão instrumentos para as interpretações dos sistemas sexo-gênero na Antiguidade. Butler conceitua sexo/gênero como um "ato performático", como um efeito produzido ou gerado, resgatando a noção de processo e de construção singular de cada sujeito, dentro de um campo de possibilidades que é reafirmado ou renegociado por meio de sucessivas "performances", ou seja, atos, práticas concretas (e não essências naturalizadas) por meio dos quais os sujeitos se constituem. Foram concepções sobre gênero como estas que deram margem ao abandono das teorias construcionistas do sujeito. Não mais havendo sexo natural nem uma única forma de ser mulher ou de ser homem. Entendeu-se que a sexualidade é envolta de rituais, linguagens, fantasias, representações, símbolos, convenções, processos profundamente culturais e plurais. Por meio da cultura, definimos o que é, ou não é, natural; produzimos e transformamos a natureza e a biologia e, consequentemente, as tornamos históricas, o que leva os corpos a ganharem sentido socialmente - $\mathrm{O}$ 'sexo' é, pois, não simplesmente aquilo que alguém tem ou uma descrição estática daquilo que alguém é: “ ele é uma das normas pelas quais o 'alguém' simplesmente se torna viável, é aquilo que qualifica um corpo para a vida no interior do domínio da inteligibilidade cultural (Butler, 2000: 155).

Por isso, pensar a respeito das práticas sexuais antigas, do amor, do Eros romano, sem necessariamente prendê-los nas concepções modernas de pornografia, obsceno, homossexual, heterossexual é um exercício e um desafio a fim de conhecer novas percepções de corpos e de relações humanas. Deste modo, neste trabalho apresento, incialmente, um debate de natureza teórica, a fim de identificar as tensões existentes entre os embates discursivos a respeito de gênero e sexualidade no mundo antigo; e num segundo momento trago algumas pinturas de relações eróticas encontradas em uma terma suburbana 
em Pompeia ${ }^{3}$, com o intuito de evidenciar as diferentes maneiras que os indivíduos interpelavam as normas. Nesse sentido, acredito que rever a documentação de cunho erótico-sexual de Pompeia significa retirá-la do isolamento e desconhecimento na qual foi submetida, e para além disso, é também uma maneira de visibilizar questões tão contraditórias e complexas a respeito do sistema sexo-gênero.

\section{Debates sobre gênero e sexualidade no mundo antigo}

As discussões sobre o sistema sexo-gênero e reflexões sobre o comportamento ou as representações da sexualidade também ganharam destaque no que concerne ao mundo antigo, tanto do ponto de vista dos historiadores quanto dos arqueólogos. Inspirados pelas novas teorias pós-estruturalistas, e sobretudo, pelo surgimento do L'Usage des Plaisirs, o segundo volume de Michel Foucault do audacioso Histoire de La Sexualité, publicado em Paris no ano de sua morte, em 1984 - junto com o volume Le Souci de Soi -, passaram a representar um novo ponto de partida para explorar a "sexualidade" na Antiguidade. Nestes dois últimos volumes de História da Sexualidade, ao voltar à Antiguidade, Foucault demarcou a diferença em relação à Modernidade nas formas de constituição do "sujeito". Segundo ele, nas culturas greco-romanas, o espaço de constituição do sujeito era uma esfera de preocupações éticas que enfatizava a liberdade e a produção de si mesmo. Na cultura ateniense dos séculos V e IV a.C., o pensador francês localizou um momento cronológico em que a subjetividade sexual tinha tomado, sem dúvida, formas muito diferentes daquelas consideradas "naturais" nas atuais sociedades do ocidente moderno.

A partir de um método genealógico, o filósofo francês tinha a intenção de traçar o desenvolvimento posterior do sujeito desejante, usando a alteridade do passado para desafiar a crença contemporânea na existência de normas universais de conduta sexual na natureza humana. Seu projeto era mapear na história do Ocidente a hermenêutica do "eu", da subjetividade. Nesse sentido, no segundo volume o autor se centrou nos textos gregos médicos-filosóficos

\footnotetext{
3 As reflexões aqui apresentadas, são de certa forma, uma continuidade a uma pesquisa iniciada juntamente com Renata Senna Garraffoni, em que destacamos alguns grafites e pinturas (as quais retomo nesta ocasião) para pensar as relações homoeróticas na Antiguidade, cujos resultados foram publicados na coleção de textos sobre Homoerotismo na Antiguidade Clássica (Garraffoni \& Sanfelice, 2014). No entanto, para esta ocasião me detenho apenas às pinturas, e desenvolvo algumas leituras das imagens e suas relações com o sítio, não apresentadas naquele momento da pesquisa.
} 
(primeiramente do século IV a.C. em Atenas) e no terceiro volume em textos greco-romanos dos dois primeiros séculos da nossa era (Foucault, 2009b; 2007); Em O Cuidado de Si (vol.3), Foucault (2007) centraliza seu estudo sobre o Império Romano dos séculos I e II d.C., percebendo uma mudança nos modos de subjetivação. O filósofo defende que o homem romano livre, cidadão e aristocrático era responsável pelo comando e organização da sociedade, e teria desenvolvido para si uma prática de temperança e austeridade sexual que marcaria sua relação de poder sobre si mesmo e sobre os outros. Desse modo, nesse período surgiram as práticas do cuidado, em que as pessoas desenvolveriam sobre si focos de atenção, resultando no que chamou de uma estética da cultura de si. Foucault ressalta que nesse contexto não é uma interdição que está em voga na moral sexual e sim a arte da existência que gravita em torno da questão de si mesmo, de sua própria dependência e independência, da maneira pelo qual pode se estabelecer a plena autonomia. E essa arte da existência acentua a importância de se desenvolver todas as práticas e todos os exercícios pelos quais se poderia manter o controle sobre si e chegar ao gozo. Para Foucault (2007), as sociedades greco-romanas compartilhariam de um ideal - em que a relação do homem com a sexualidade estaria intimamente ligada às relações sociais, a identidade de um homem livre ou cidadão se pautaria na defesa da masculinidade e da virilidade.

Com o desenvolver destas discussões, a década de 1990 foi marcada por um aumento de interesse sobre o comportamento sexual no mundo grecoromano, as investigações mostravam que os conceitos de "homossexual" e "heterossexual" eram categorias inapropriadas para compreender as experiências do mundo antigo. Nesse universo, a questão da masculinidade se tornou o tema de constantes discussões, e é de consenso nestes debates que o fato de um homem ter relações sexuais com outro homem ou mulher não era suficiente para identificar a sua categoria sexual, como ainda é pressuposto pelo senso comum em dias atuais. A relação entre dois homens era compatível com o casamento, e embora a ética sexual fosse exigente, complexa e múltipla, não havia um único código regendo o comportamento sexual. A posição do sujeito como ativo ou passivo é defendido por parte da historiografia como grande fronteira moral que demarcava os indivíduos e não a preferência hetero ou homossexual (Holmes, 2012; Walters, 1997; Halperin, 1990; Winkler, 1990; Feitosa L. C., 2014; Flores, 2017). No universo romano, em especial, a representação mais frequente é aquela em que o homem aristocrático e cidadão exerce a função ativa, tanto no campo sexual como no social.

Para compreender melhor essa situação, destaco as interpretações de Judith Hallett e Marilyn Skinner (1997), que propõem uma leitura focada nas práticas sexo-sociais. As autoras ressaltam as modificações ocorridas entre os anos 70 
a.C. e 200 d.C., período de transição de República a Principado Romano, em que Roma foi transformada por longas décadas de guerra civil, uma República governada por uma oligarquia senatorial e um principado quase que hereditário, elementos fundamentais para definir a organização social deste período. Embora os costumes ancestrais, mos maiorum, estivessem cada vez mais distantes da vida diária dos romanos, eles continuavam a servir como referência para a conduta que se esperava dos sujeitos que compunham a elite de Roma, estando, assim, presentes na cultura letrada. As autoras afirmam também que os códigos sexuais foram afetados pelas relações de clientela, que estavam em todas as esferas da vida, em todos os níveis da sociedade, mediando hierarquia por meio de amicitia, uma instituição que tem como premissa a troca voluntária de favores entre o patronus e seus cliens. Também regido pelo poder patriarcal: a sociedade romana era totalmente patriarcal, sendo pater, não apenas o indivíduo que teve filhos, mas aquele que detinha todo o poder no seio da família, que tinha o direito sobre a vida dos filhos, esposa e escravos. Nesse sentido, estas contingências históricas e sociais seriam projetadas na relação domínio-submissão da sexualidade romana, criando documentos em que narrativas sexuais, sobretudo as literárias, serviam como um ordenamento do sistema semântico com o intuito de moldar as elites sociais.

Jonathan Walters (1997) faz uma interessante discussão nesse sentido, ao explorar a ideia de impenetrabilidade dos corpos, afirma que se tomássemos a maioria das fontes textuais romanas, dos séculos I a.C. e I d.C., como veículos da ideologia sexual masculina daquela época, estes indicariam o que se esperava do homem romano, o uir, um papel de dominante no ato sexual, enquanto o status de submissão era atribuído ao seu objeto de sedução e desejo. Desse modo, o protocolo social-sexual romano definiu o homem romano (vir) como um penetrador impenetrável, sendo este um padrão conceitual que caracterizava àqueles de alto status social, como o indivíduo que é capaz de defender os limites do seu corpo dos assaltos e invasores de todos os tipos. Assim, o corpo do cidadão homem (vir) era visto como inviolável, legalmente protegido contra a penetração sexual, agressões e torturas - tinha a imunidade corpórea. O vir traria consigo uma identificação de integridade física sob dois aspectos: um social, porque para essa elite não seria apropriado o castigo corporal - quando um de seus membros infringia alguma norma, seria punido por meio de multas ou exílio, e não com castigos físicos, apresentados como um insulto a sua dignitas; e outro sexual, na medida em que sua atividade lícita seria aquela que lhe caberia penetrar.

Walters ressalta também que o termo (vir) está restrito aos adultos do sexo masculino: os homens que não atingiram o estágio da vida adulta não são chamados viri, em vez disso, são descritos como pueri, adulescentes, ou outros 
termos que os definem como pessoas que ainda não cresceram. Escravos do sexo masculino e também ex-escravos, mesmo adultos, não são normalmente chamados viri: a designação preferida é homines (que também é usado na literatura de elite para denominar camadas populares e os homens de má reputação), ou pueri. Vir, portanto, não se limita a indicar um adulto do sexo masculino, refere-se especificamente aos homens adultos que são cidadãos romanos nascidos livres, que estão no topo da hierarquia social romana.

Mais recentemente, o classicista Guilherme Gontijo Flores (2017) oferece um panorama interessante sobre como os romanos encaravam alguns aspectos do homoerotismo, relacionado sobretudo a uma concepção mais poética da vida. Primeiramente Flores, apresenta a experiência grega de pederastia como instituição social (um convívio do homem mais velho, erastés, com o jovem aprendiz, erômenos, que incluía uma vida sexual até que o jovem amadurecesse), isso para dizer que em Roma a pederastia não foi uma instituição social, mas foi um tipo de inspiração na estética grega, que por sua vez esteve presente em vários poemas romanos. Para esse autor, isso explica porquê os documentos literários possuem essa fronteira tão demarcada entre aquele que era ativo e aquele que era passivo de uma relação sexual. Não que não houvesse uma afetividade sexual entre os romanos, mas os documentos escritos apontam geralmente valores presentes nos discursos sociais, que por sua vez, possuem uma forte inspiração grega. O autor também nos assevera que por meio dos vestígios do passado "podemos compreender minimamente o que se fala no espaço público, mas isso não representa toda a sociedade, já que inevitavelmente, o que é considerado imoral e obsceno permanece em grande parte fora do discurso que foi conservado" (2017: 15).

Mesmo que resumidamente trouxe algumas reflexões para compreender os debates em torno das identidades de gênero em Roma, que se resume basicamente em um tipo de distinção binária entre os homens livres, que poderiam penetrar sexualmente qualquer outra pessoa, de qualquer gênero e de status inferior, o penetrado. No entanto, considero importante ressaltar que para além de discutir a questão da virilidade, muitos estudos vêm buscando compreender os significados dos relatos que nos foram deixados, enfatizando a subjetividade e o desejo ${ }^{4}$.

\footnotetext{
${ }^{4}$ Renato Pinto considera, inclusive, que o termo 'passivo' seja problemático, pois pode dar a entender que os parceiros sexuais penetrados estivessem tolhidos do prazer do sexo na Roma antiga. (Pinto, 2011: 113). No entanto para fins metodológicos iremos utilizar os termos 'ativo' e 'passivo' mas tendo em mente que estes termos precisam ser interpretados com cuidado, como Feitosa nos alerta, ao afirmar que existe sempre o risco de tomarmos o papel do "penetrado" como essencialmente submisso e sempre vítima de sua condição de passivo, inoperante na relação sexual. (Feitosa, 2005: 15).
} 
Lourdes Conde Feitosa (2005) afirma que outras fontes, além da literatura aristocrática (geralmente de natureza jurídica ou filosófica, de narrativas históricas e de retórica) podem auxiliar na composição de variados discursos. Por exemplo, por meio dos textos não oficiais, como Ovídeo e Petrônio, é possível questionar o ideal de submissão e fidelidade atribuído às mulheres, e o de austeridade e comando relacionado aos homens quando analisados no âmbito da afetividade, já que evidenciam, mesmo para as elites, campos de ação feminino e masculino diversificados e até mesmo contraditórios. De encontro a esta perspectiva, Guilherme Gontijo Flores defende que também por meio da literatura pode haver uma possibilidade de encontrar vestígios da vida privada e das relações eróticas "ainda que sob camadas e mais camadas de jogos poéticos, repetições e lugares comuns" (2017: 21), como é o exemplo de alguns gêneros e subgêneros da poesia antiga, que podem trazer descrições e vivências do afeto homoerótico.

Portanto, questionamentos aos modelos teóricos rígidos e generalizantes em relação à identidade masculina e feminina na sociedade romana têm estimulado os estudiosos a pensar a variedade de significados que os comportamentos sexuais de gênero poderiam assumir em uma população tão heterogênea quanto esta. Como comentado, muitas representações deste erotismo ficaram fora de cena, e, é a partir disso que acredito que cultura material erótica pompeiana se torna um grande recurso para explorar novas abordagens e sujeitos da Antiguidade romana. Diante disso, as análises de outros documentos, que vão além dos literários tradicionais, reavaliam os tipos de relações estabelecidas entre os indivíduos e os papéis sexuais e sociais assumidos na organização social romana. Como os trabalhos de Antonio Varone (2002), que recupera as inscrições amorosas nas paredes de Pompeia. Ao trazer grafites que fazem menção aos deuses, aos relacionamentos com prostitutas e declarações de amor, Varone almeja evidenciar uma sociedade que não conhecia nem o sentimento de culpa, nem o puritanismo ou a hipocrisia da literatura moderna, uma sociedade em que não havia o obsceno, em que mesmo as expressões que nosso senso de moralidade considerariam como indecente, poderia se evidenciar o amor.

Lourdes Feitosa (2005), usando-se dos mesmos recursos, discutiu diferentes aspectos acerca das práticas sexuais romanas a partir dos grafites e um dos pontos mais relevantes de sua abordagem é indicar como essa documentação escrita, a partir da experiência de vida das camadas populares, contrapõe-se com os modelos definidos pela historiografia moderna do que é "ser romano" durante o Império. A proposta de Feitosa, é contrapor a historiografia tradicional que defendia uma masculinidade baseada na virtude política e do autocontrole das emoções para a construção da noção de "homem romano", 
fatos que podem ser conflitantes mediante a análise dos grafites ${ }^{5}$, nos quais aparecem homens implorando pelo amor de mulheres e dividindo com elas suas alegrias e tristezas cotidianas, explicita posturas muito diferentes daquela do soldado viril, ainda amplamente difundida no imaginário moderno.

Por fim, acredito que outro excelente contraponto para analisar a sociedade romana é a cultura visual-artística, uma vez que a linguagem pictórica aumenta as referências a respeito das práticas sexuais do mundo romano, indo além dos ideais propostos pelos documentos literários. Gostaria, então, de problematizar no próximo item, essa relação da sexualidade com a vida cotidiana romana, a partir de uma terma de Pompeia, mais precisamente, e propor que o sexo e as práticas sexuais eram um componente natural da vida.

\section{Corpos múltiplos: atos performáticos em representações homoeróticas na Terma Suburbana de Pompeia}

A colônia romana Pompeia é uma cidade ao sul da Península Itálica, foi soterrada pelo Vulcão Vesúvio no ano de 79 d.C, sendo redescoberta por escavações arqueológicas em meados do século XVIII. Num primeiro momento a descoberta da cidade possibilitava encontrar vestígios quase que intactos do mundo romano, anfiteatros, teatros, circo, templos, etc. E essas foram as buscas das primeiras empreitadas arqueológicas, contudo, Pompeia trouxe outras possibilidades para a compreensão do mundo antigo - artefatos da vida cotidiana. Das cinzas do vulcão, foram retiradas inúmeras casas, com seus objetos de uso cotidiano, os registros de seus sentimentos e crenças (tanto em grafites nas paredes, como em pinturas murais). No entanto, durante as escavações também foram encontrados uma série de objetos de cunho eróticosexual, e por terem sido considerados pornográficos ou inapropriados para a moral cristã, durante décadas este tipo de documento foi trancafiado em salas de museus, ou destruído, fazendo com que muitos vestígios da Antiguidade tenham sido invisibilizados.

Destaco essas informações, porque está muito relacionado com os discursos modernos sobre a sexualidade, pois foi a partir de alguns objetos encontrados na cidade de Pompeia que se cunhou o termo "pornografia". O arqueólogo alemão C. O. Müller se tornou um dos precursores do uso da expressão, quando, em 1850, se deparou com inúmeros objetos "obscenos" em suas escavações e consultou um dicionário de língua grega, encontrando a palavra pornographein (escrever sobre prostitutas), o que ele considerou adequado para se

5 A título de curiosidade deixo um exemplo: Amethusthus nec sine sua Valentina (CIL, IV, 4858), [Ametusto não vive sem sua Valentina]. Grafite encontrado no muro entre as portas número 12213 da Região VII, 15. (Feitosa, 2005: 116). 
referir aos objetos encontrados no sítio (Clarke, 2003; Voss, 2012; Sanfelice, 2013). De tal modo, durante quase dois séculos, pinturas e outros objetos foram catalogados como pornográficos e obscenos, e os que não foram destruídos no momento do achado, foram trancados em salas vigiadas, onde o público não teria acesso, no Museo Nazionale di Napoli. Posturas como essa, acabaram por restringir as possibilidades de estudar essa documentação, bem como silenciaram as diferentes maneiras de se representar as práticas sexuais. Nesse sentido, questionar as noções de pornográfico e sua relação com a materialidade, significa retirá-la do isolamento, por isso, selecionei para este debate uma abordagem sobre pinturas de relações homoeróticas encontradas em uma terma suburbana em Pompeia.

A Terma Suburbana de Pompeia, foi escavada em 1987, sob supervisão de Luciana Jacobelli, que publicou uma monografia a respeito deste sítio (1995), devido aos avanços teóricos-metodológicos, desde medos da década de 1930, aderiu-se a prática de deixar as pinturas em sítio, portanto as pinturas desta terma ainda estão in loco. A respeito dos banhos públicos, segundo Paul Veyne (2009), havia um antigo provérbio entre os romanos afirmando que "o banho, o vinho, e Vênus consomem o corpo, mas são a verdadeira vida", destacando o quanto esta experiência era importante no cotidiano romano. Sabe-se também que no dia a dia romano, havia apenas três lugares em que os sujeitos tiravam suas roupas: cubicula (quarto), termas e lupanaria (prostíbulos), mas era nos banhos que os indivíduos mais expunham o seu corpo ao olhar do outro. Dessa forma, a nudez definia a experiência do banho público como algo único na sociedade romana (Laurence, 2010). Desde a época helenística, a função do banho não era apenas permitir a higiene, mas proporcionar um modo de vida desejável entre todos. As termas eram decoradas com mosaicos, esculturas, pinturas e arquiteturas suntuosas que proporcionariam o bemestar dos frequentadores, os quais muitas vezes iam até lá apenas para se aquecer.

As termas poderiam ser separadas entre masculinas e femininas, ou partilhadas entre ambos os sexos em horários alternados, o ritual ligado aos banhos consistia em chegar ao apodyterium (um quarto em que se deixavam as vestimentas), ir para uma sala de exercícios e depois seguir por salas cada vez mais quentes até chegar a uma piscina com água fria. Os banhos envolviam uma experiência corpórea individual, com impressões de calor, frio e nudez, resultando em uma série de sensações. Além disso, o banho era um prazer social experimentado coletivamente, havia um prazer em estar entre a multidão, gritar, encontrar pessoas, escutar as conversas, saber de casos curiosos, jogar e se exibir. Os cidadãos despendiam de muitas horas nas termas, pois este espaço propiciava um momento de lazer, de exercício, e, sobretudo, o cuidado com a aparência (Clarke, 2007). No caso específico deste 
banho pompeiano, tanto Clarke (2001) quanto Jacobelli (1995) acreditam ser compartilhado por homens e mulheres. Comprovado pela arquitetura do local, pois, geralmente, os banhos mais claros, construídos com vidros, eram destinados a banhos segregados; já os mais escuros, tinham a característica de serem compartilhados, como é o caso aqui presente (Laurence, 2010). No apodyterium (cômodo colorido na planimetria abaixo) há pinturas com cenas de sexo explícito, sendo as únicas imagens pompeianas com reproduções homoeróticas. Dentro deste cômodo, haveria supostamente uma prateleira para depositar as roupas, e, em cima desta, estariam localizadas as pinturas e os números de I a VIII (map 1).

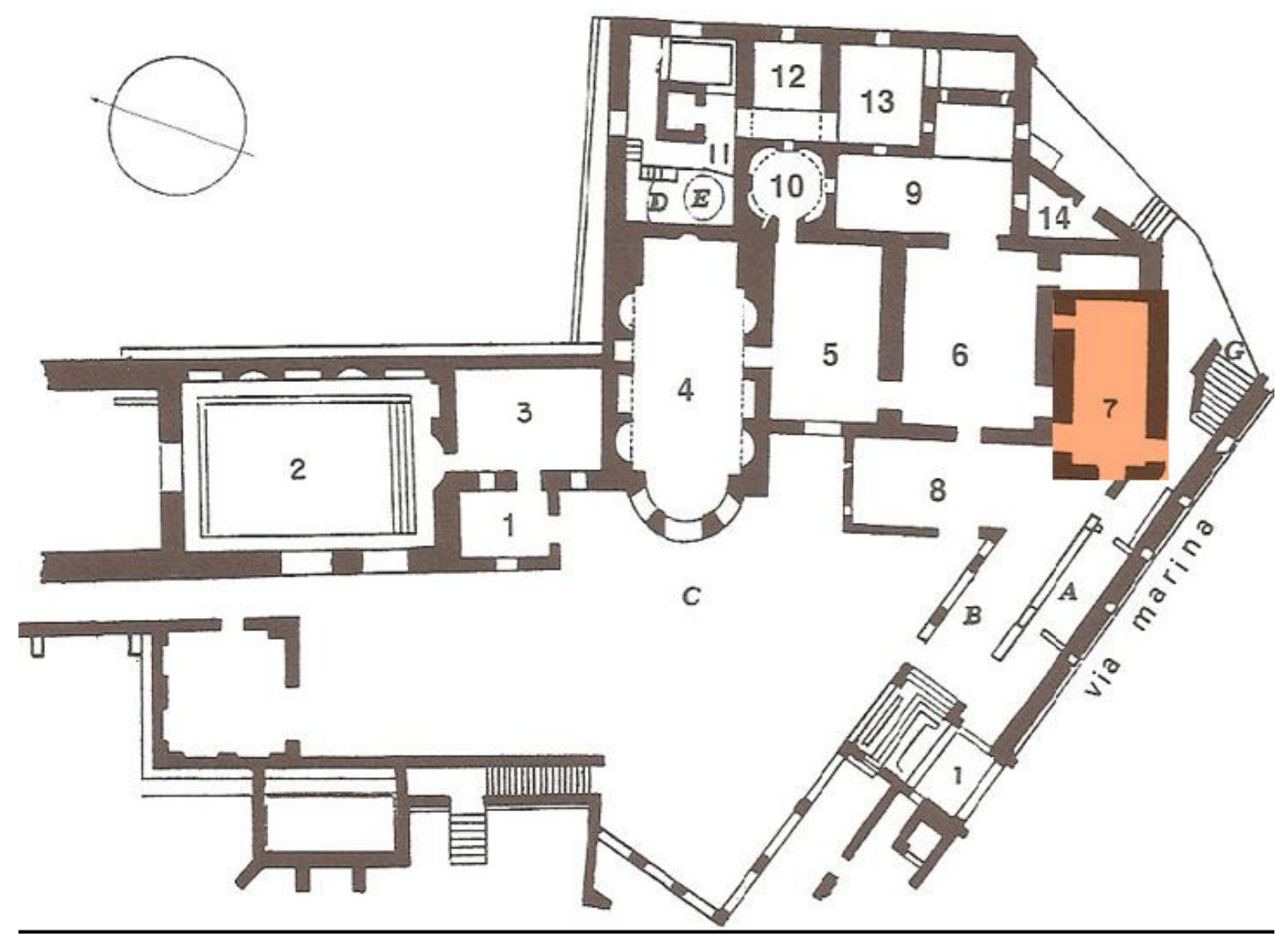

Mapa 1. Termas Suburbanas de Pompeia. Fonte: (Clarke, 2001, p. 213) 


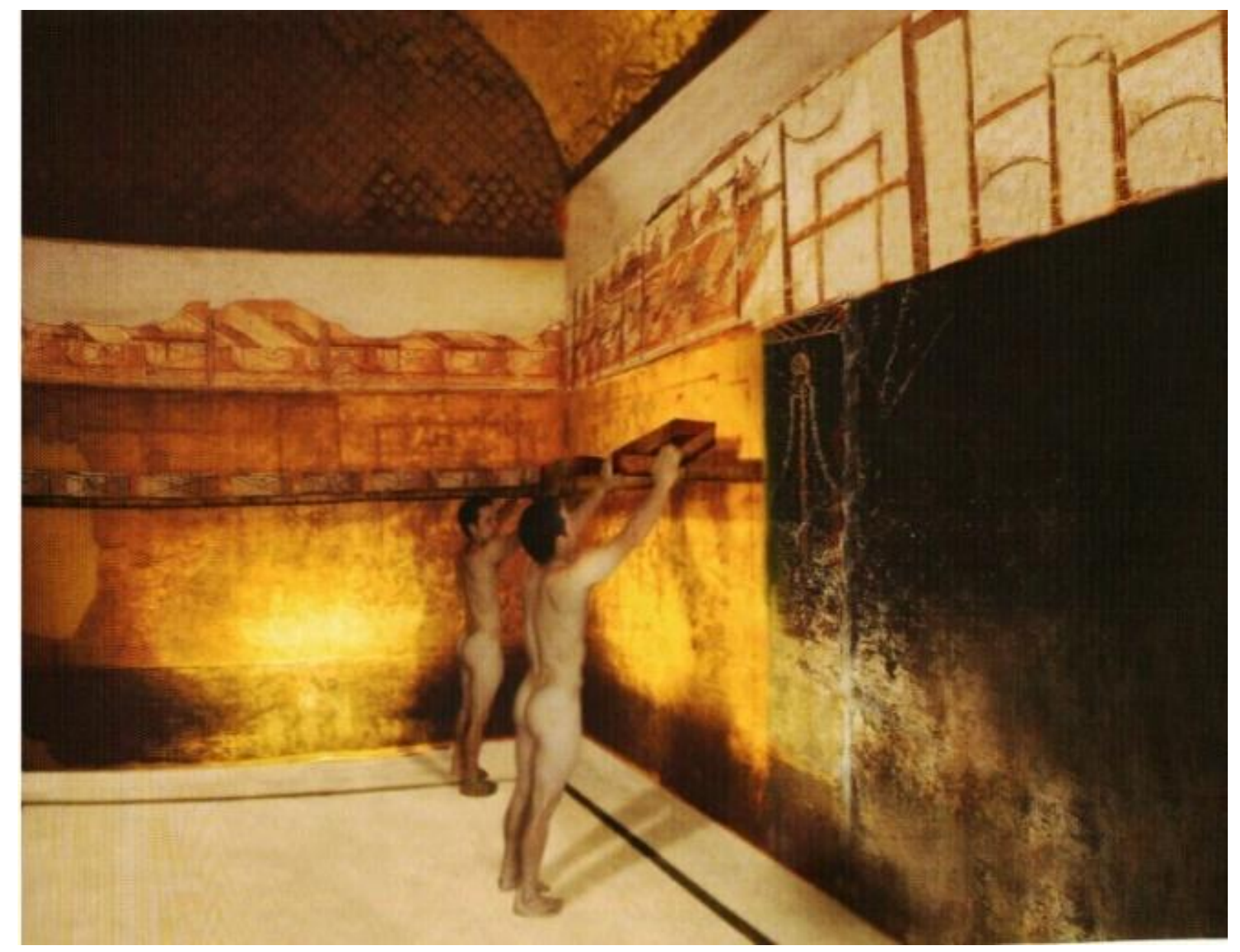

Figura 1. Reconstituição do apodyterium (Terma Suburbana). Fonte: (Clarke, 2003: 117)

A primeira cena da sequência exibe um homem seminu deitado, apoiando-se em seu cotovelo e penetrando uma mulher. A dama tem o cabelo castanho, curto, e está totalmente nua, leva uma joia em seu tornozelo esquerdo, e ao seu lado há a presença de um peixe. Ela aparentemente encara o observador, e está sentada sobre o pênis do amante (fig. 2).

O que chama atenção nesta cena é perspectiva utilizada pelo pintor, que nitidamente diminuiu o corpo masculino, talvez seja um recurso para enfatizar a figura feminina. A posição sexual representada é muito comum na cultura romana, Apuleio (Apul., Metam., II,4) definiu esta postura como Venus pendula "mobilem spina quatiens pendulae Veneris fructu me satiavit"6, Ovídio

6 "Al hablar así, subió a la cama, se recostó poco a poco sobre mí y en rápida y lasciva agitación de su torso dio con su vaivén plena satisfacción a mi amor, hasta que, embriagado el espíritu zos del otro para confundir nuestras almas mutuamente rendidas" (Apuleyo, 1978) - Tradução para o español de Lisardo Rubio Fernandez. 
(Ovid., Ars.Am., III, 777) se refere a ela como "parua uehatur equo"7 eram as mulheres que cavalgavam ${ }^{8}$, presente também nos grafites pompeianos:

Mea vita, meae deliciae, ludamus parumper:

hunc lectum campum, me tibei equom esse putamus (CIL, IV, 1781)

[Minha vida, minha delicia, vamos cavalgar um pouquinho: Vamos imaginar que este leito é um campo liso.... $]^{9}$

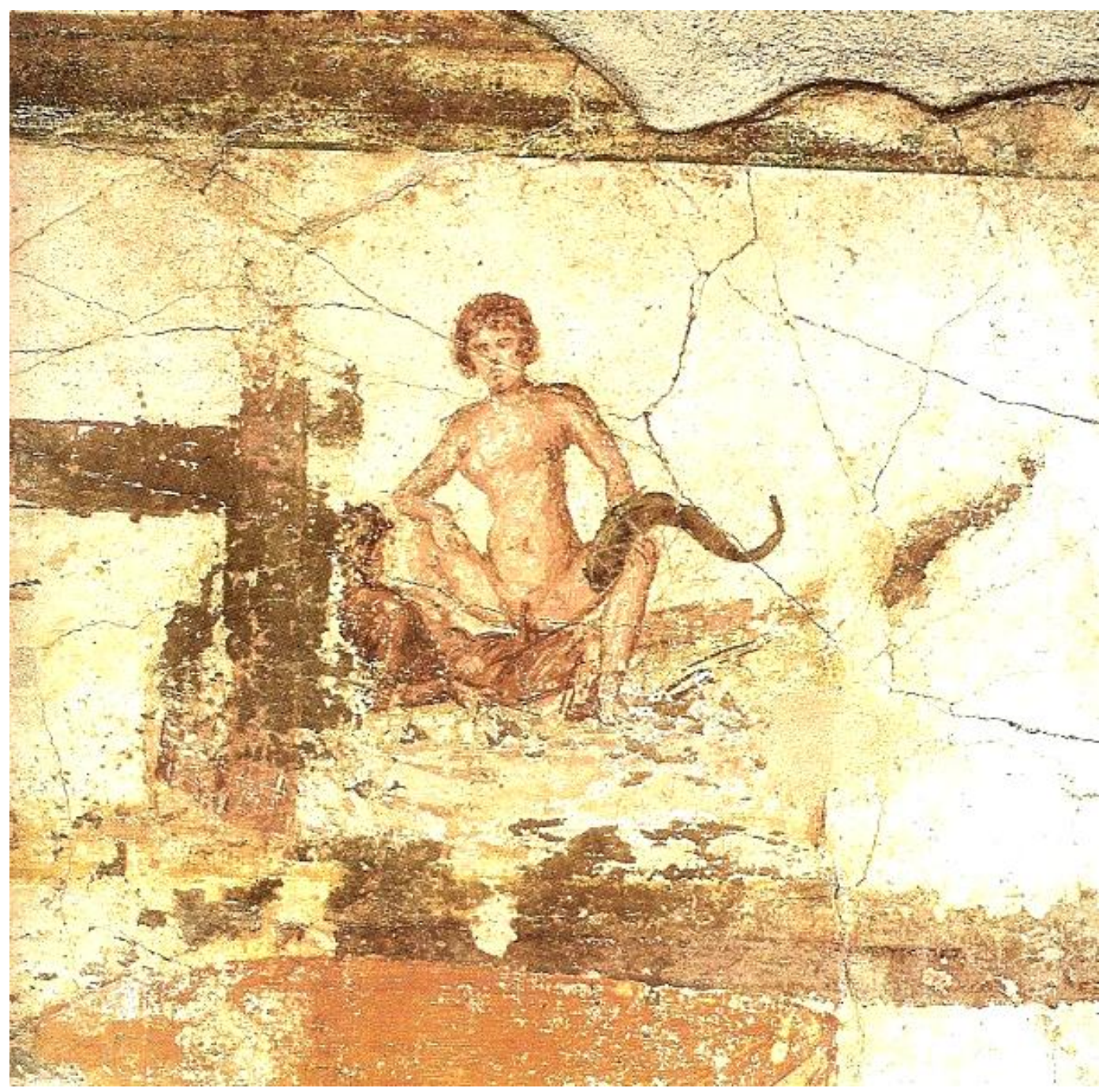

Figura 2. Cena I- Homem com uma mulher na cama. Fonte: (Clarke, 2001: anexo 09)

7 "La que es pequeña monte a cabalo: como era grandullona, la tebana nunca cabalgava sobre Hector. (Ovidio, Amores o Arte de Amar, 1989) - Tradução para o espanhol de Vicente Cristóbal López.

${ }^{8}$ Mulier equittans, Cf. Jacobelli, 1995: 36; Cavicchiolli, 2004.

9 Grafite encontrado na entrada de uma Basílica (Grafitos Amatorios Pompeyanos, Editorial Gredos, Madrid, España, 1990, p. 127 - tradução de Caratelli). 
Embora exista uma vertente historiográfica que interprete esta postura sexual da mulher como passiva e submissa: "è al servizio del piacere del suo signore e si spinge fino a far lei tutto il lavoro; se 'cavalca' l'amante che se ne sta fermo è per servilo" (Veyne, 1978:. 53-54 apud Jacobelli, 1995: 38)10; conforme Catherine Johns (1990) esta posição é a busca do prazer próprio da mulher, e, além disso, faz com que a parceira possa olhar melhor toda a relação, ou seja, tal atitude poderia ser interpretada como a emancipação sexual da mulher romana. Mesmo que, normativamente, sob os códigos sexuais romanos, esta relação fosse vista como homem-ativo/mulher-passiva, a imagem nos proporciona observá-los sob outra perspectiva, em que ambos podem sentir prazer e não necessariamente se submeterem apenas ao serviço do prazer do outro, afinal, como já proclamava Ovídio (Ovid., Ars.Am., II, 728-9) "O prazer total se chega quando o homem e a mulher estão rendidos por igual" 11 .

A cena seguinte também trata de uma representação sexual entre um homem e uma mulher, no entanto, é um pouco atípica na iconografia erótica. O homem está ajoelhado sob a cama enquanto a mulher está deitada de costas para ele, esse é um padrão representativo nos artefatos espalhados pelo Império, contudo, é uma posição típica em que um homem penetra outro homem, é incomum entre relações de sexos opostos, uma vez que a posição sugere a penetração anal. Nesta cena, bem como na anterior, o corpo feminino é privilegiado, destacando, possivelmente um prazer que foje às normas, tendo em vista que não era permitido às mulheres este tipo de relação, por não ser voltada para a procriação.

Já a terceira cena, embora seja comum em representações eróticas gregas, é bem rara nos registros visuais romanos: uma mulher praticando felação em um homem. O homem retratado está sentado sob a cama e em uma de suas mãos segura um pergaminho, já a mulher está ajoelhada no chão praticando sexo oral em seu parceiro. Nesta imagem também encontramos uma relação atípica, pois, tanto na literatura antiga quanto nos grafites ${ }^{12}$, há indícios de que a felação é uma prática socialmente condenada, relacionada geralmente às prostitutas, isso porque os romanos tinham uma conviç̧ão da função sagrada da boca, um orgão destinado a proferir discursos e a oratória pública - e, curiosamente, o homem tem em suas mãos um pergaminho, remetendo a prática da oratória.

\footnotetext{
10 "A parceira está ao serviço do prazer do seu senhor e vai ao ponto de realizar todo o trabalho, cavalga-se o amante imóvel é para servi-lo".

11 (Ovídio, A Arte de Amar, Editorial Gredos, Madrid, España, 1989, p. 422).

12 Cf. (Feitosa, 2005; Varone, 2000).
} 


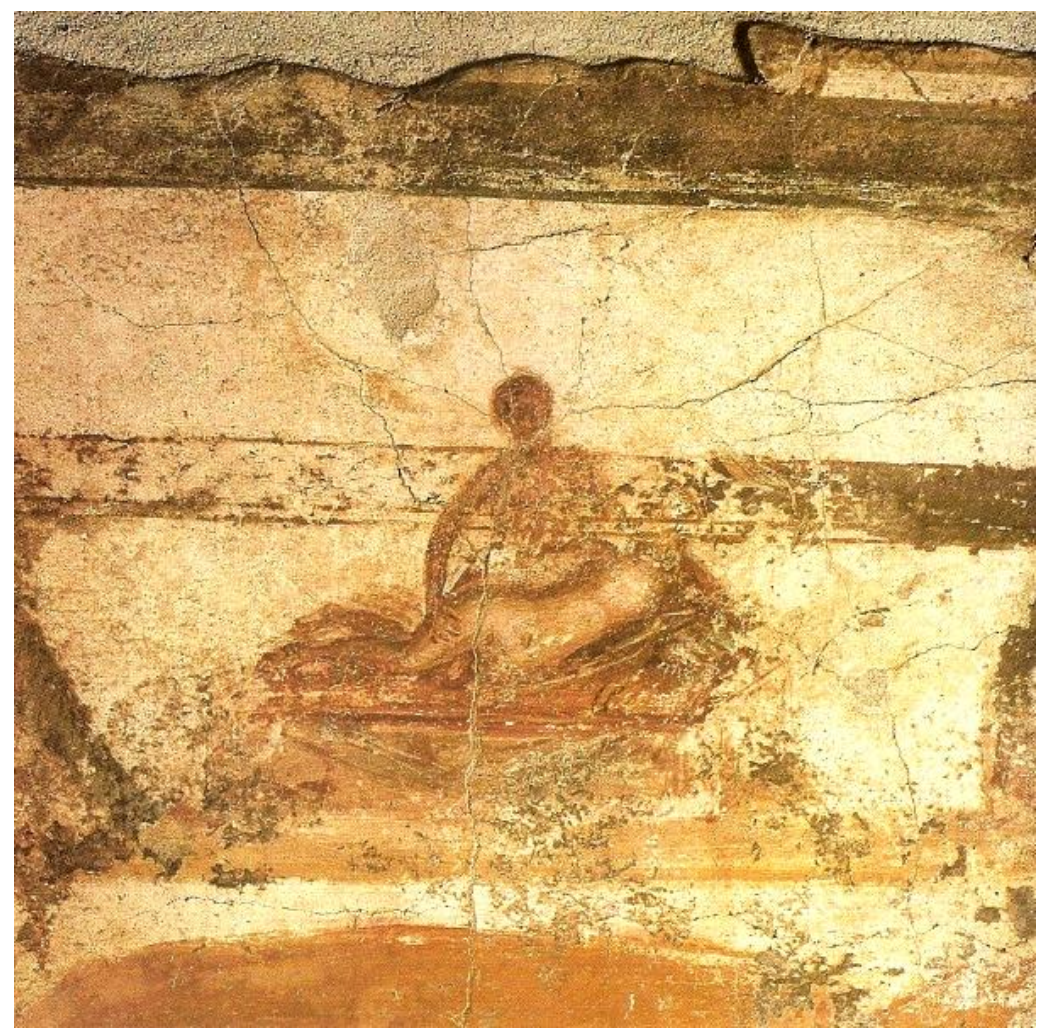

Figura 3. Cena II- Homem com uma mulher de costas. Fonte: (Clarke, 2001: anexo 10)

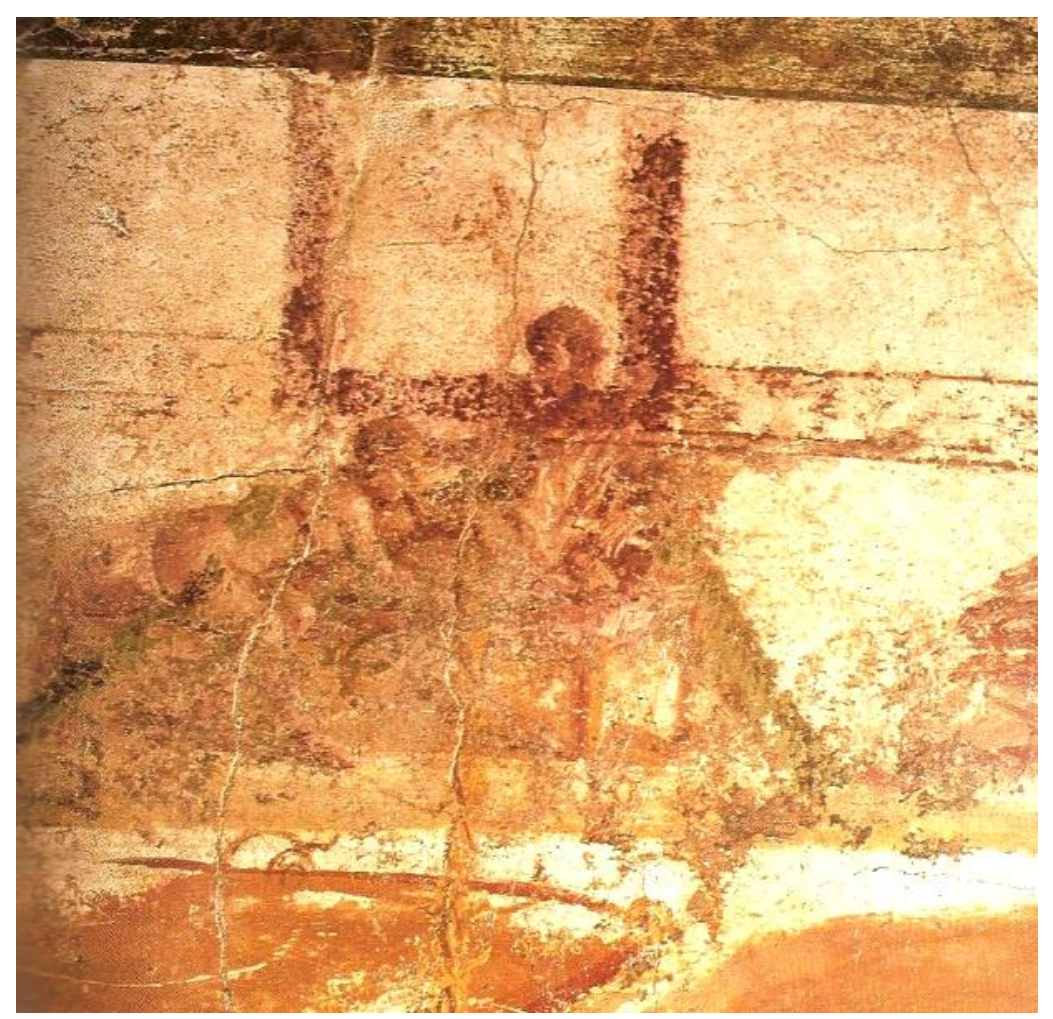

Figura 4. Cena III- Mulher praticando fellatio. Fonte: (Clarke, 2001: anexo 11) 


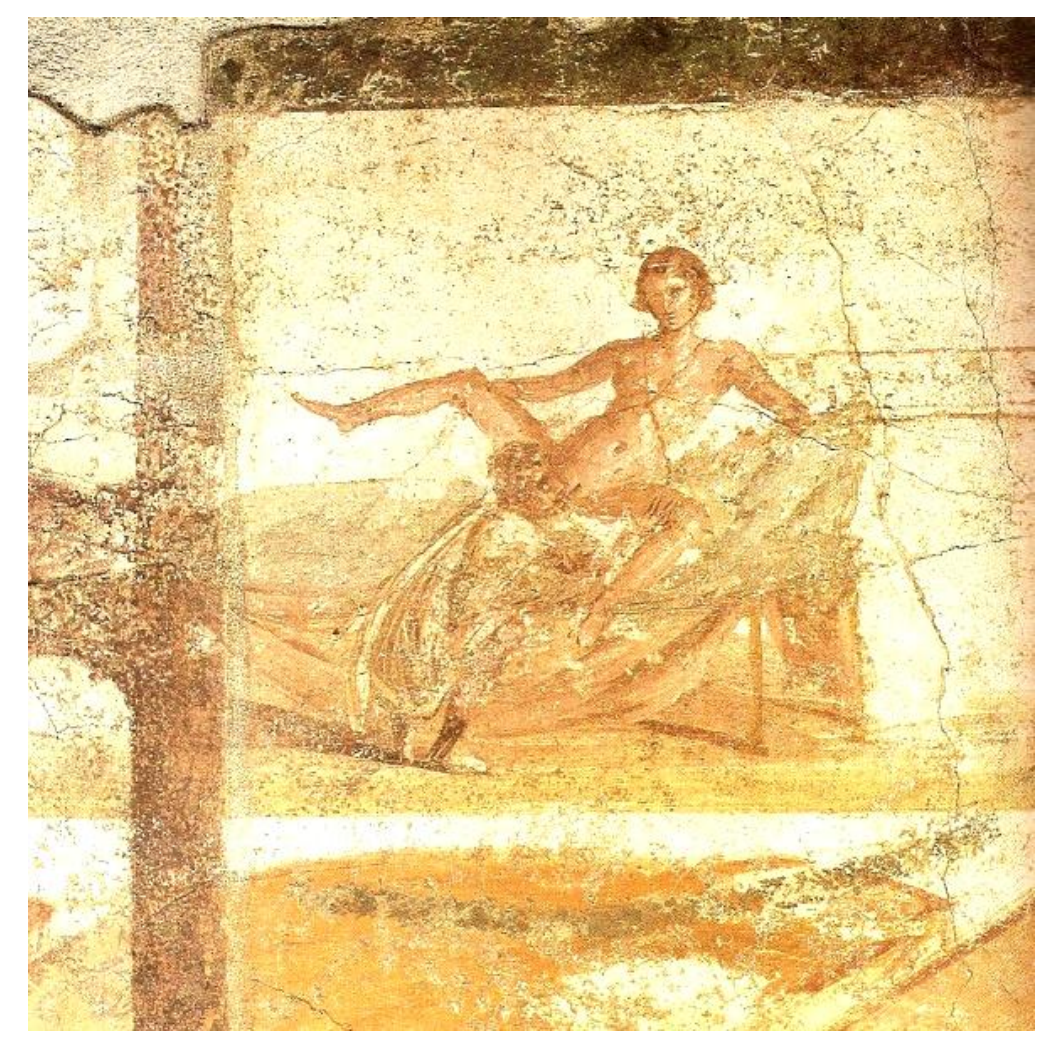

Figura 5. Cena IV- Homem praticando cunnilingus. Fonte: (Clarke, 2001: anexo 12)

A cena de número IV, é um pouco mais audaciosa, temos a inversão do ato anterior, pois aqui o homem pratica o sexo oral (cunnilingus) na mulher. Esta está adornada por joias, parece utilizar um cinturão de Vênus (o colar que está em seu pescoço), muito comum nas representações desta deusa, que tinha como propriedade inspirar o amor (Sanfelice, 2012), conforme se pode observar na figura 5. Esse adorno se torna significativo, pois pode ser interpretado como uma forma de inspirar o amante a dar prazer feminino, e também demarca um elevado status social desta mulher. Esta cena é muito relevante para a nossa discussão, na medida em que, aponta o extremo do deslocamento dos gêneros tradicionais. A mulher, sempre nomeada como passiva, torna-se ativa neste momento, e o homem o inverso, sendo usado "vaginalmente" por uma mulher (Parker, 1992). Deste modo, o que chama atenção é o poder exercido por esta mulher, enquanto ela está se deleitando de prazer, o homem estaria colocando a sua vida em desgraça, por contaminar sua boca, o que seria o ápice da corrupção masculina.

A cena $\mathrm{V}$ muda um pouco de teor, uma vez que há um indivíduo em pé e outro deitado. Apesar da nitidez da imagem estar um pouco comprometida, há uma reconstituição proposta por Jacobelli, que deixa mais claro o que se passa no intercurso sexual representado. 


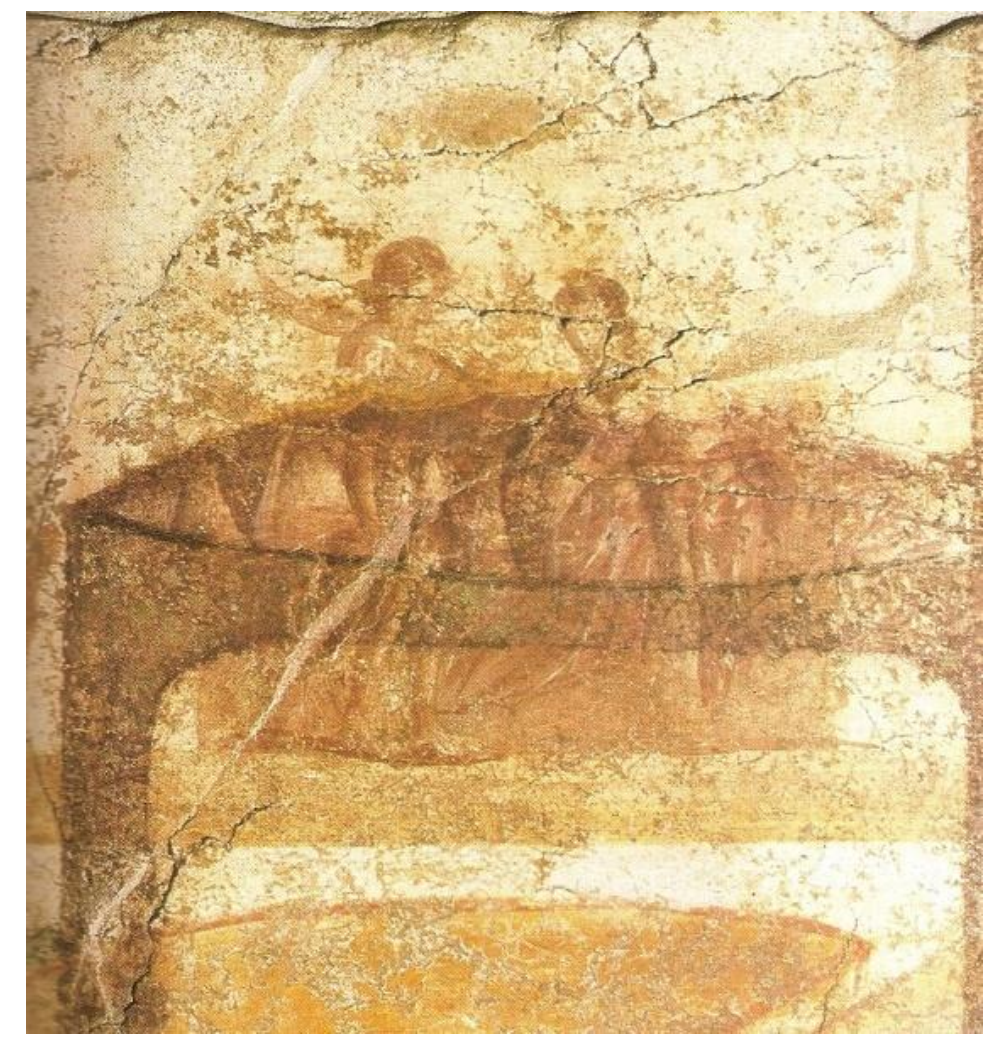

Figura 6. Cena V- Duas mulheres na cama. Fonte: (Clarke, 2001: anexo 13)

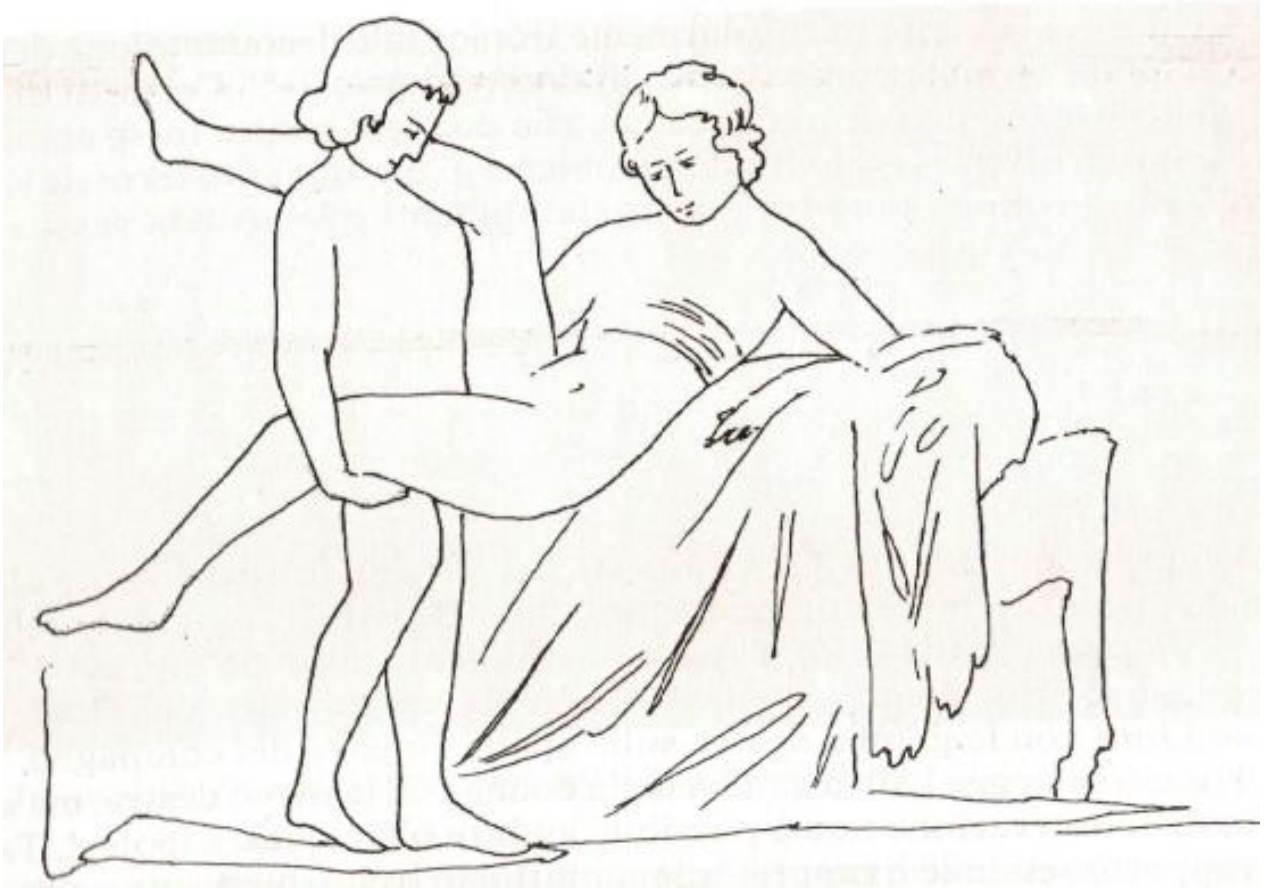

Figura 7. Reconstituição da Cena V por Jacobelli. Fonte: (Jacobelli, 1995: 48) 


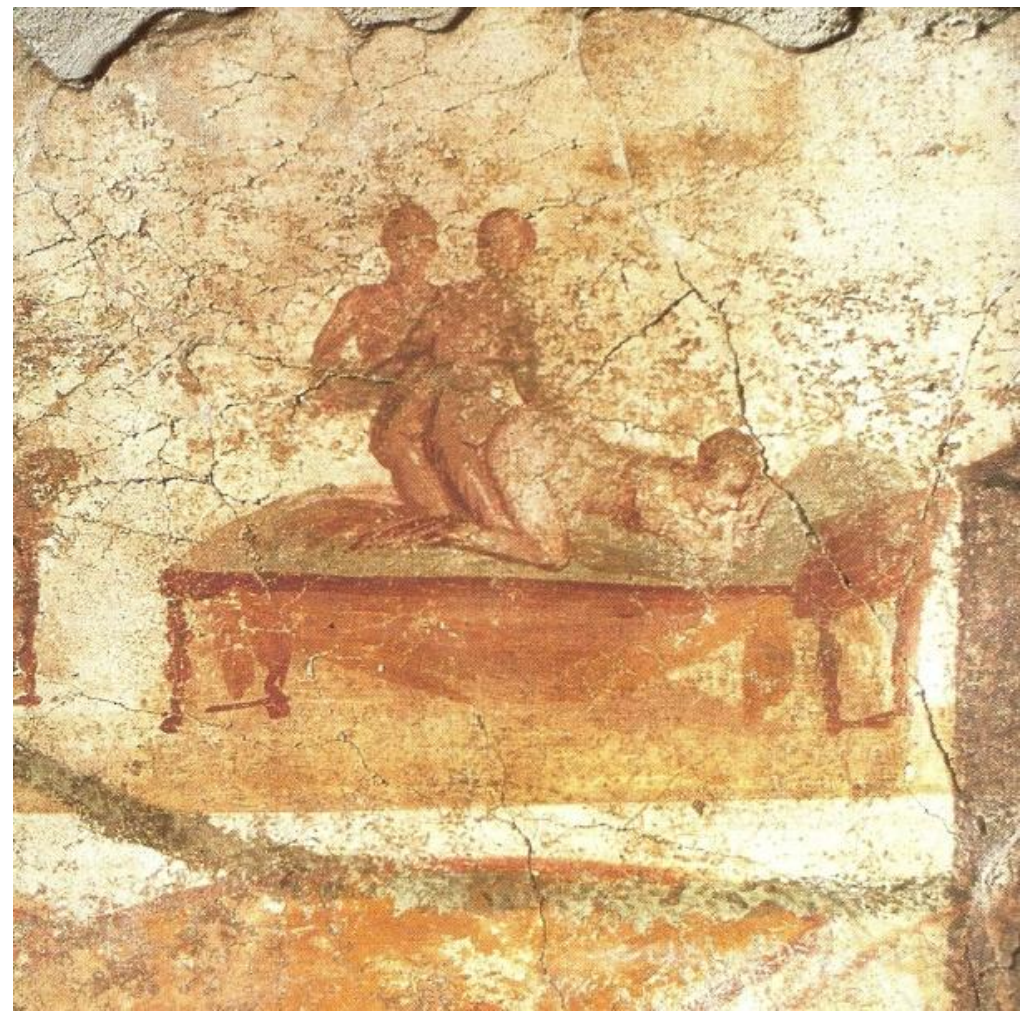

Figura 8. Cena VI- Dois homens e uma mulher na cama. Fonte: (Clarke, 2001: anexo 14)

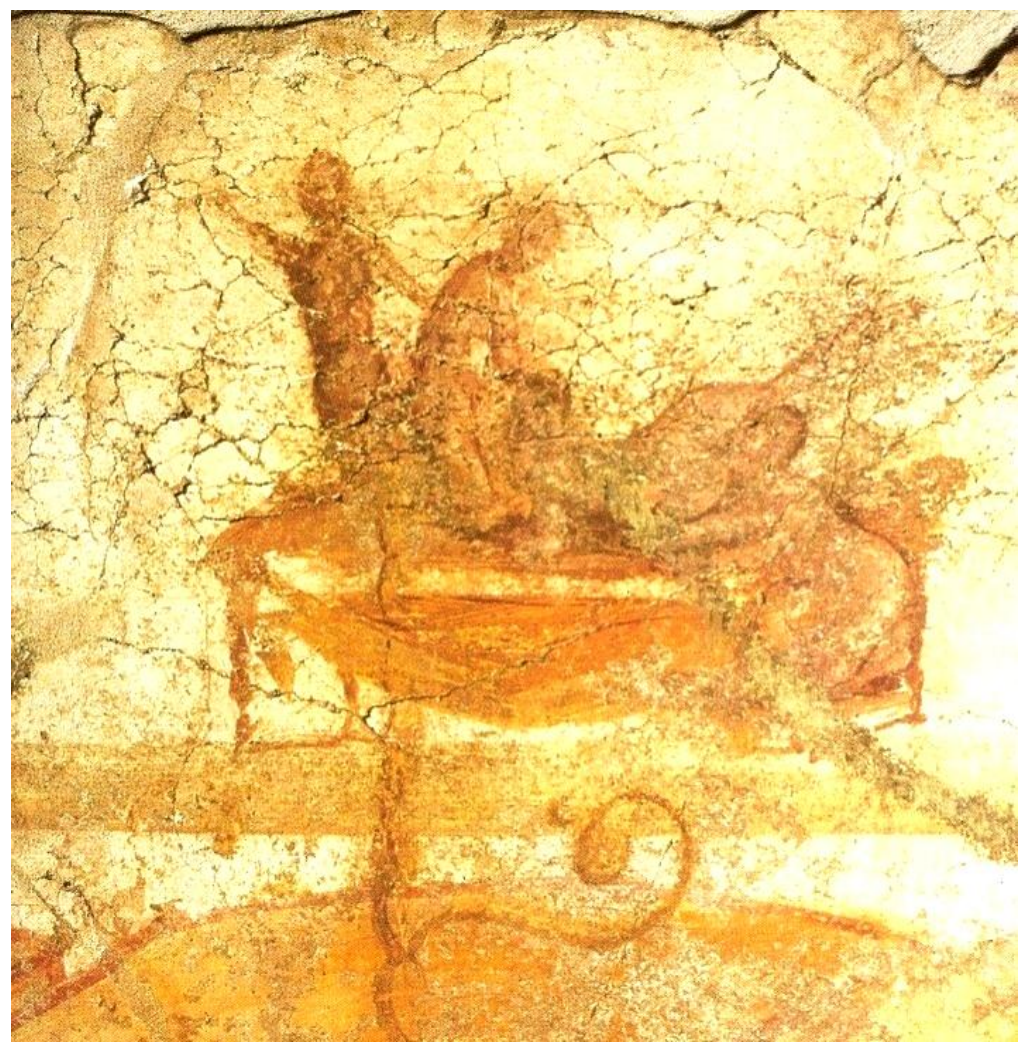

Figura 9. Cena VII- Dois homens e duas mulheres na cama. Fonte: (Clarke, 2001: anexo 15) 
Para Jacobelli (1995), trata-se de uma cena comum em que um homem penetra uma mulher. No entanto, duvido um pouco desta proposição, pois, se as cenas aumentam em seu grau de contravenção às normas, esta imagem estaria um tanto deslocada nesta sequência. Portanto, acredito que são duas mulheres imitando uma posição que seria mais comum ao padrão representativo de um homem se relacionando com uma mulher. E, para além disso, destaco que em todas as imagens os homens são representados com um tom levemente mais escuro de pele, e, nesta imagem, embora não seja nítida a figuração dos sujeitos, não se diferencia a tonalidade da tez. Nesta cena, de relação homoerótica entre duas mulheres, parece existir um falso intercurso sexual, em que uma mulher utilizaria um dildo, prática chamada de tribades, que configuraria numa prática masculinizada. Muitos acreditavam que isso ocorria porque a mulher possuía um imenso clitóris, fazendo dela uma parceira ativa, assumindo o papel de um homem, atravessando as fronteiras do gênero, e também violando às normas de condutas sociais (Parker, 1992), papel geralmente atrelado às prostitutas. Contudo, assumir que estas mulheres seriam prostitutas, seria um contrassenso se comparássemos com a cena anterior, de número IV, em que a mulher ativa, aparentemente é um membro da aristocracia, devido aos seus adornos, pela tez clara, etc. Dessa forma, o que deixaria esta cena irreverente é o fato de duas mulheres se darem prazer, desorganizando as normas, e dispensando os serviços de um homem.

Na cena número VI há a representação de um trio na cama em plena atividade sexual. Há uma mulher que está de joelhos, sendo penetrada por um homem, que seria supostamente o ativo da relação (vir), no entanto, ele também é penetrado por outro homem, assim, ele assume o papel de passivo (pathicus). No caso da mulher, não está claro se ela está praticando sexo anal ou vaginal, mas tudo sugere que seja uma penetração em que ela também seja contraventora, deixando de ser a femina para se tornar um puer. Esta imagem é instigante, pois são as raras as representações de trios eróticos, tanto iconograficamente quanto na cultura escrita. Mas fica clara a ambiguidade do status social da figura do meio, que assume o papel de ativo e passivo, contrapondo os modelos sexuais que pressupõem que sempre há um indivíduo ativo e um passivo na relação (fig. 8).

A cena de número VII apresenta quatro sujeitos se relacionando na cama, dois homens e duas mulheres. Da direita para a esquerda, podemos observar uma mulher praticando cunilíngua em outra que, por sua vez, também faz sexo oral em um homem, e este homem está servindo como o homem passivo da relação, sendo somente o último a manter seu status intacto. Esta representação também é interessante, pois há uma mulher que está se relacionando com um homem e com uma outra mulher ao mesmo tempo, na literatura latina não há registros deste tipo de prazer feminino, e essa figura se 
torna tanto passiva quanto ativa, bem como o homem penetrado que recebe a felação. Tal imagem infringe todas as fronteiras sócio sexuais (fig. 9).

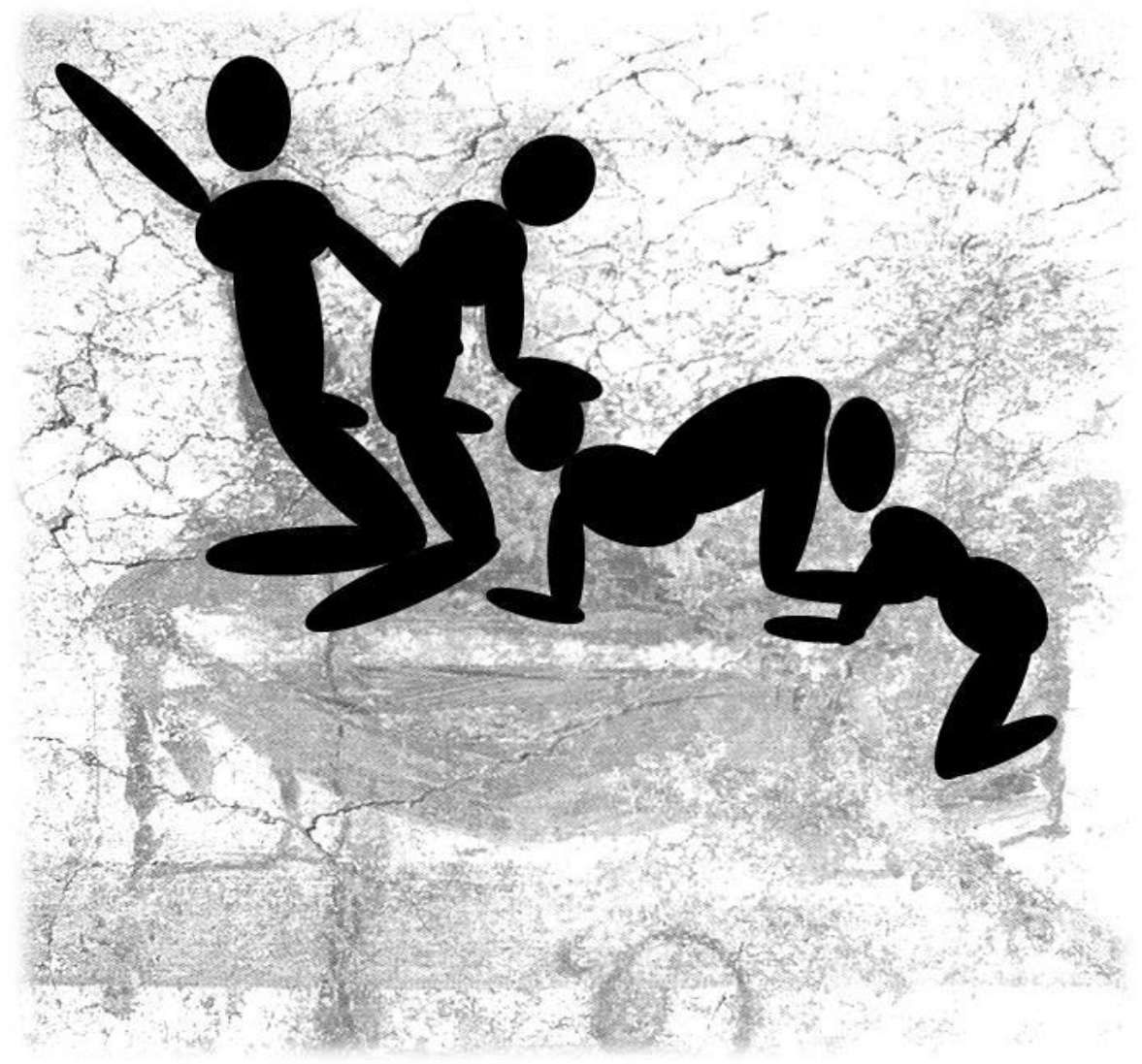

Figura 10. Reconstituição da cena por Marco Sanfelice. Fooonte: (Clarke, 2001: plate 15)

Em uma sequência em que os parceiros sexuais vão aumentando numericamente, provavelmente esperaríamos que a última cena fosse a representação de cinco pessoas na cama ou que os sujeitos representados estivem em posições acrobáticas. Entretanto, temos na oitava cena a representação de uma única pessoa, um artista, um homem nu, com enormes testículos, em frente a uma mesa, com um livro, um pergaminho na mão. Esta imagem pode ser considerada uma caricatura, de um poeta - um literato, alguém importante - que está com uma doença em seus testículos, provavelmente, uma hidrocele bilateral, o que condenaria a sua potência fálica, e o tornaria uma mera testemunha da cena. Tendo em vista que a palavra latina testis pode referir-se tanto aos testículos quanto a testemunha de algo, essa imagem também traz uma ambiguidade: aquele que em vez de se lançar ao sexo, como os anteriores, é apenas testemunha, observa as relações e faz uma leitura. 


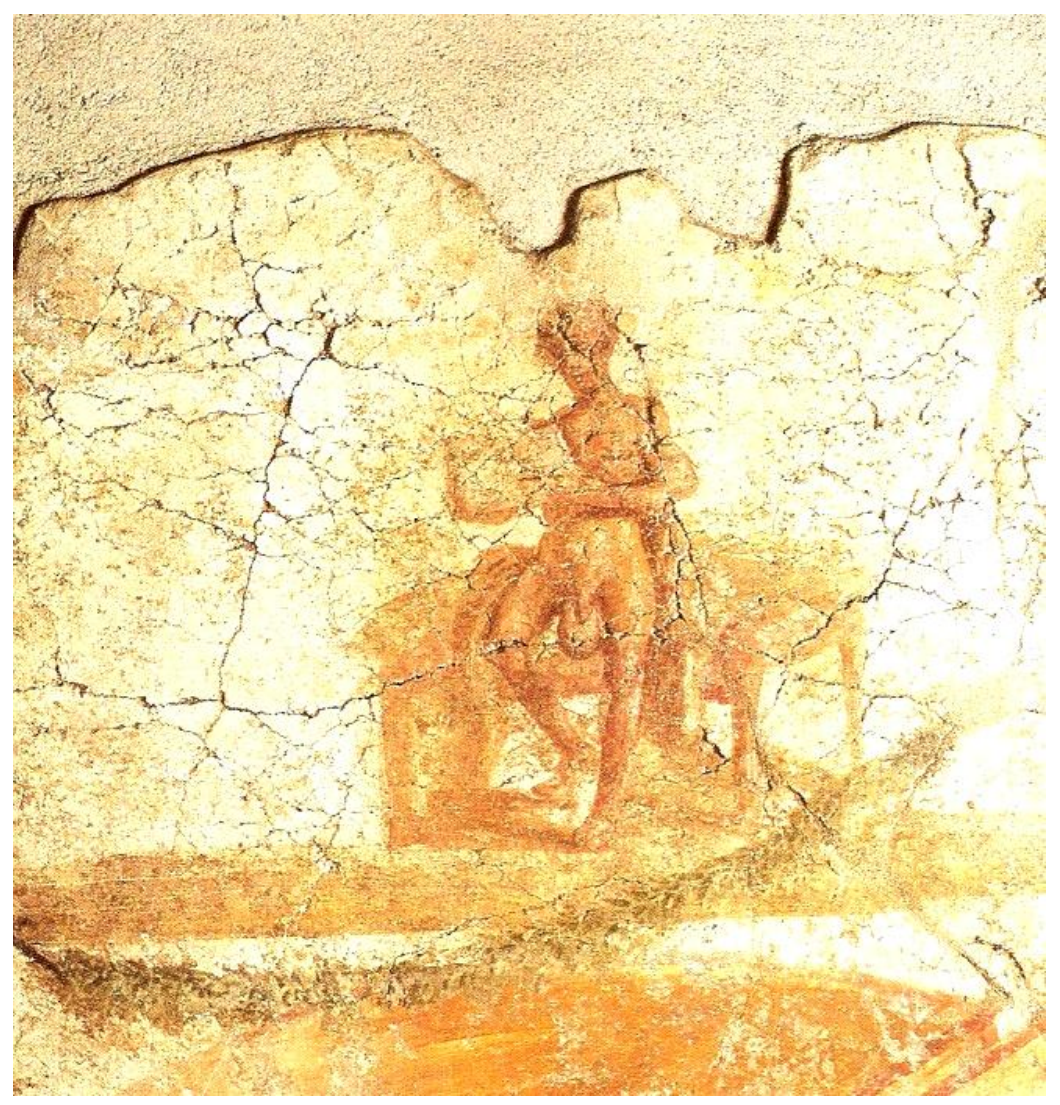

Figura 11. Cena VIII- Caricatura de um poeta com hidrocele. Fonte: (Clarke, 2001, anexo 16)

Com relação as interpretações deste conjunto de imagens, de modo geral, devido as representações de sexo explícito, por muito tempo colocou em dúvida a utilidade do local, pois se reconhece na sociedade romana, o uso das termas para vender serviços sexuais (Laurence, 1996). Contudo, proponho outra interpretação para essas pinturas, acredito que não se trata de uma casa de prostituição, pois basta compararmos este ambiente com os lupanares de Pompeia, que possuem pinturas que retratam exclusivamente relações heteroeróticas. Para além disso, considero oportuno destacar que toda sorte de pessoas tinha acesso a tais imagens, era um ambiente público frequentado por homens e mulheres de diferentes classes sociais e, inclusive, por crianças, que recebiam instruções sobre o corpo e os comportamentos, como já mencionei. Luciana Jacobelli (1995), também desassocia as imagens do estímulo erótico, para a autora são apenas uma maneira de facilitar a memorização do local onde as roupas estavam guardadas e também uma forma de estimular o riso. Essa informação levantada por Jacobelli é muito importante, seria um riso provocado pelo fato destas imagens denotarem um outro lado das práticas sexuais romanas, consideradas tabus pela elite romana.

Para além disso, acrescento outras possibilidades para o riso, acredito na probabilidade de que este ambiente, possa possuir uma poderosa função apotropaica, comum no universo romano em que figuram-se objetos 
relacionados tanto com a religiosidade quanto com a sexualidade (Clarke, 2007). Conforme Funari (2003), no mundo antigo as representações e ilustrações fálicas eram usadas, especialmente, para afastar as forças negativas (a raiz do verbo grego apotropein - "desviar"), atraindo assim boas vibrações e prosperidade. O símbolo fálico, portanto, era um ícone da fertilidade, tendo assim, uma conotação extremamente positiva:

O membro masculino em ereção era associado, na Antiguidade clássica à vida, à fecundidade e à sorte. (...) $\mathrm{O}$ falo não apenas afastava o mal como trazia sorte e felicidade. Recorde-se que a palavra latina felicitas, a um só tempo, "felicidade" e "sorte", ambos os sentidos derivados do sentido original de felix, "fértil" (Funari, 2003: 316).

Essa relação do falo com a fertilidade, felicidade, também pode ser observada em outra situação em Pompeia (fig. 12).

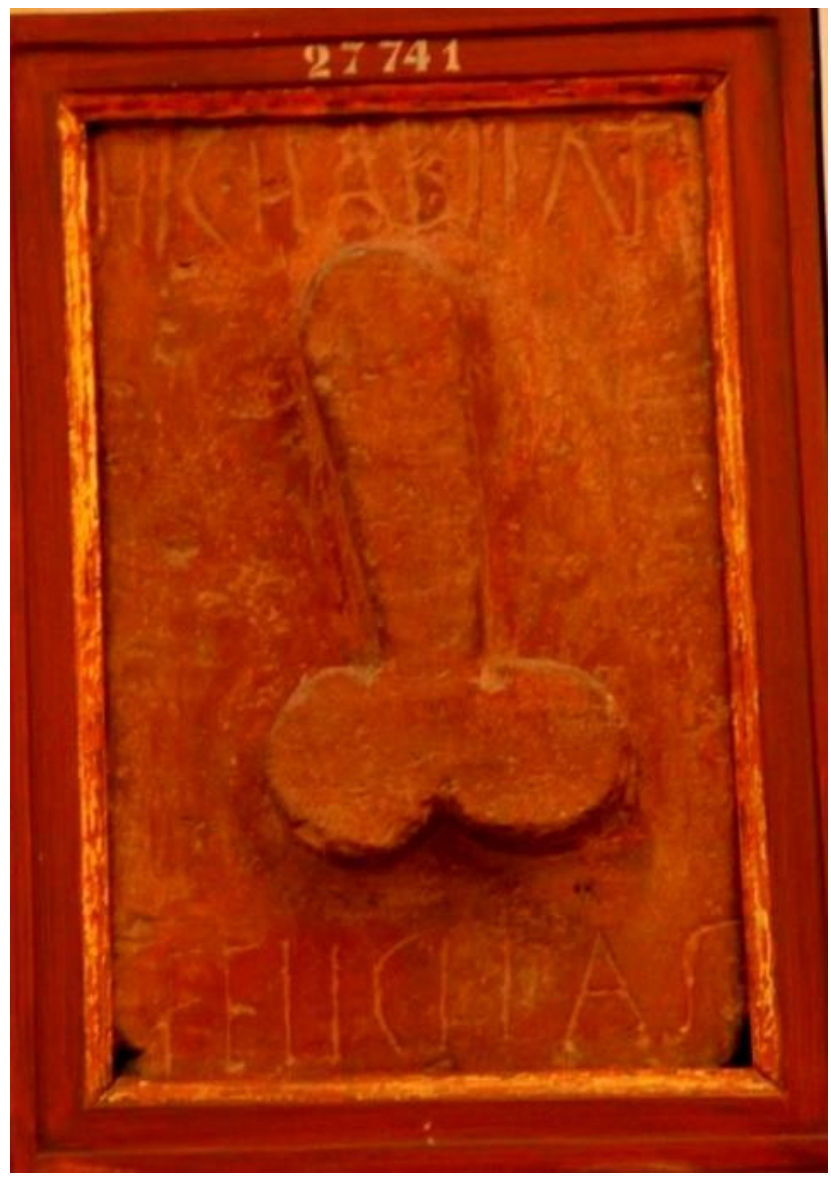

Figura 12. Placa com Falo e inscrição Hic Habitat Felicitas. Fonte: Fotografia de Marco Sanfelice - Outubro de 2013. Local de Conservação: MANN- GS - Inv. 27741. Tamanho:24x50 cm. Local do Achado: Pompeia (IV, 6, 18) Datação: I d.C. 


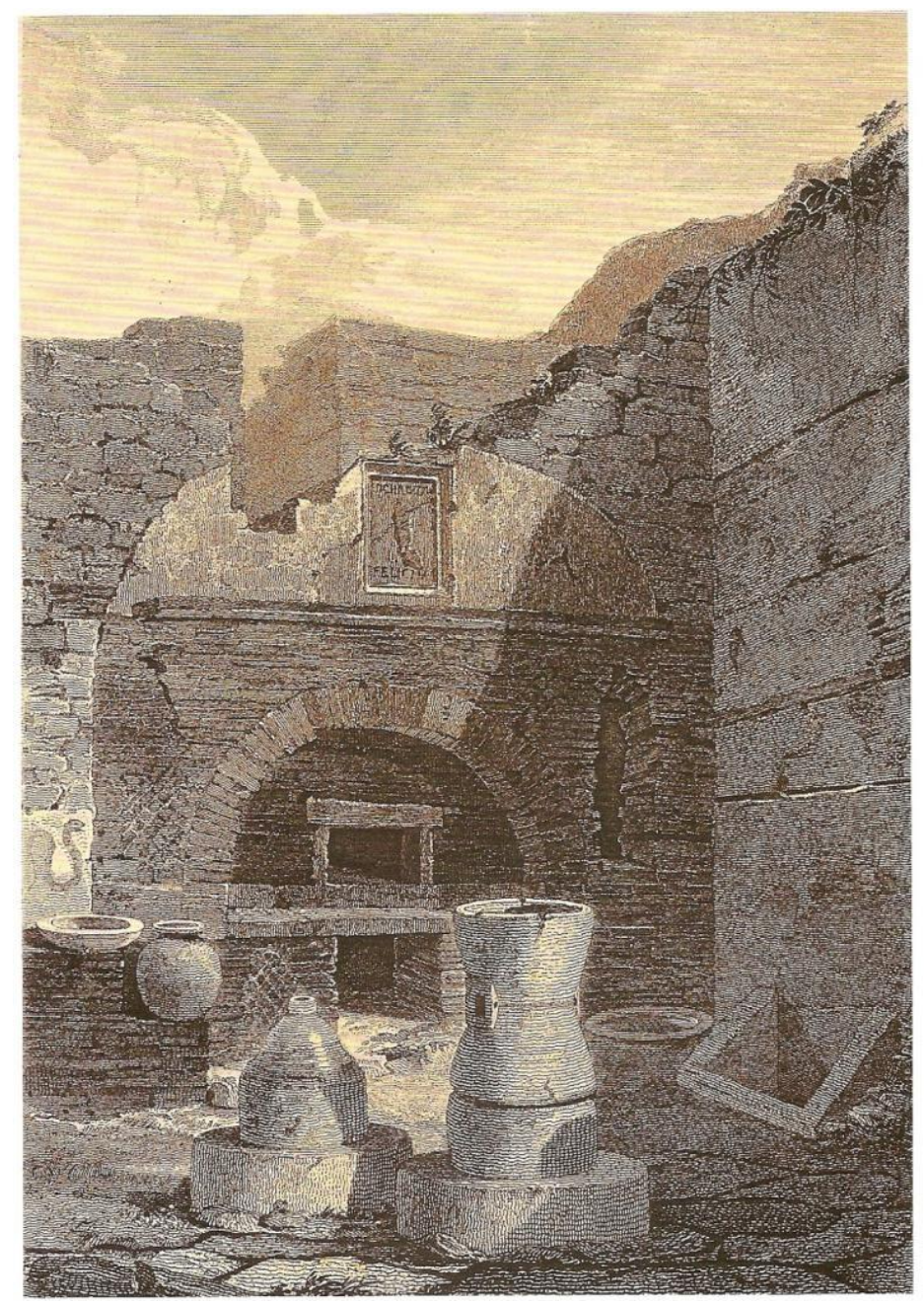

Figura 13. Registro do local de achado da placa. Fonte: Fotografia de Marco Sanfelice Outubro de 2013. Local de Conservação: MANN- GS (Catálogo explicativo da imagem).

A inscrição latina "Hic Habitat Felicitas" significa "Aqui mora a felicidade" ou, como propôs Funari (2003, p.320), "Aqui mora a felicidade e a sorte", ou seja, o falo não apenas afastava o mal como trazia sorte, felicidade e prosperidade para os negócios. Ao percebermos que a placa está localizada em cima de um forno de pão, pode-se inferir que tinha como objetivo o próprio crescimento do pão, assim como a mentula cresce e se torna phallo, com o pão aconteceria o mesmo processo, e, consequentemente, aumentaria a venda do produto.

Fora de contexto pompeiano, mas de grande relevância e singularidade, apresento um mosaico encontrado na entrada de uma casa (Casa do Mau Olhado - 150 a.C.), na antiga cidade da Antioquia, este representa essa relação direta do falo contra o mau olhado. $\mathrm{Na}$ imagem podemos observar o falo voltado para o olho, assim como a presença do pássaro, do cachorro, do escorpião, da serpente e do tridente como fortes elementos combatentes a essa energia ruim que poderia adentrar a casa (fig. 14). 


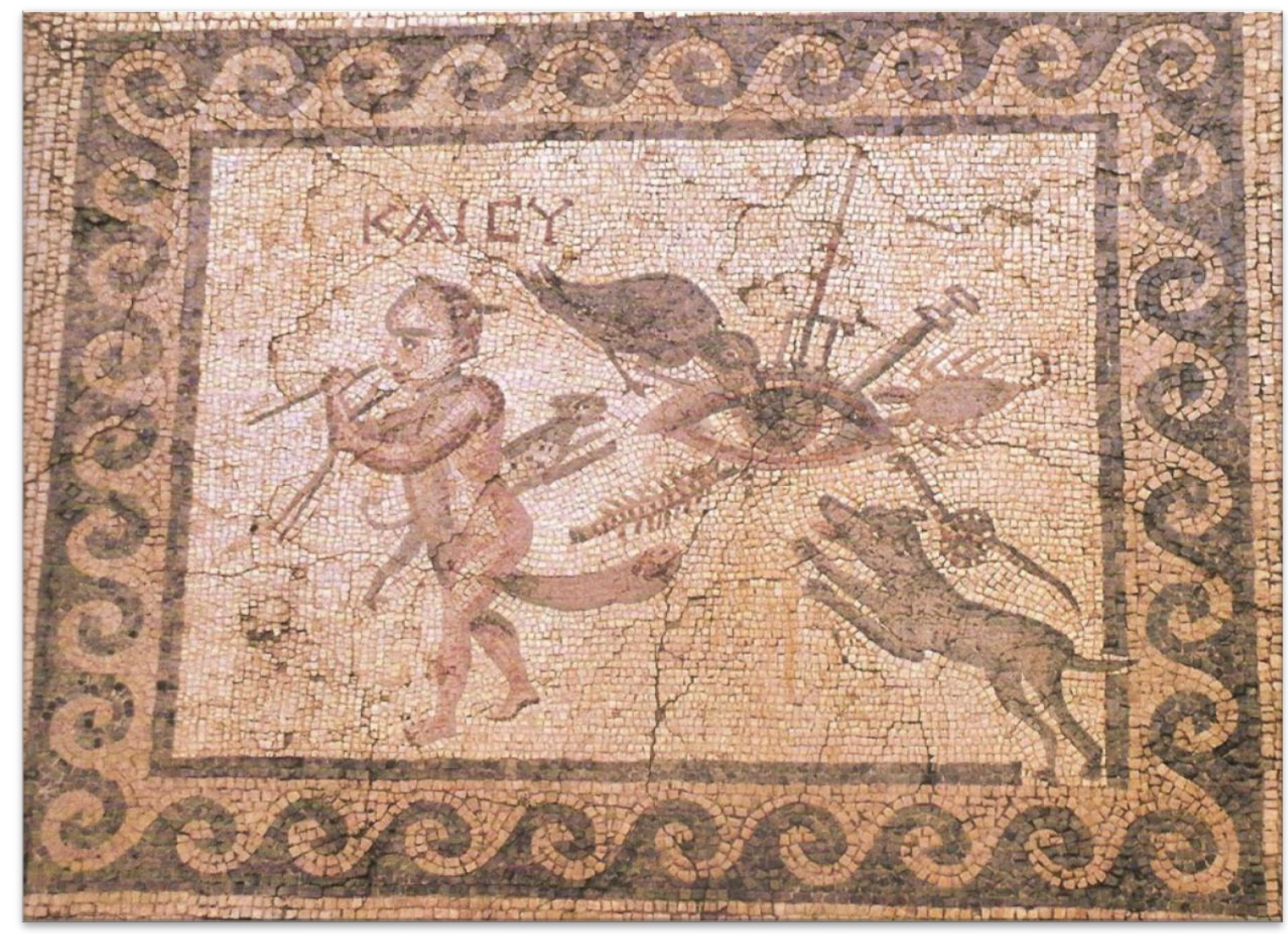

Figura 14. Afastar o mau olhado, a inveja (invidere "não ver" - não ver a si e sim aos outros), o olho fascinado, na inscrição "O mesmo pra você". Fonte: (Clarke J. , Roman Sex: 100 B.C. to A.D. 250, 2003, p. 109)

Nessa representação, um elemento primordial para afastar o mau olhado seria a presença do pequeno homem retratado, um anão, sendo esse um motivo de riso para a cultura romana. John Clarke (2007) nos esclarece que entre os romanos era comum o hábito de rir daqueles que estavam fora dos padrões de beleza - nesse caso, anões, gigantes e pessoas com deformidades eram motivos de gargalhadas e, por consequência, afastava-se toda a energia negativa. Essa situação vem de encontro com a última cena da nossa sequência, que representa a figura do poeta com hidrocele, com deformidade em seus testículos, podendo significar o fechamento de um ciclo de imagens apotropaicas. Conforme Funari (1994), há uma possibilidade que a deformidade seja efetivamente um símbolo de boa sorte (fig. 15). 


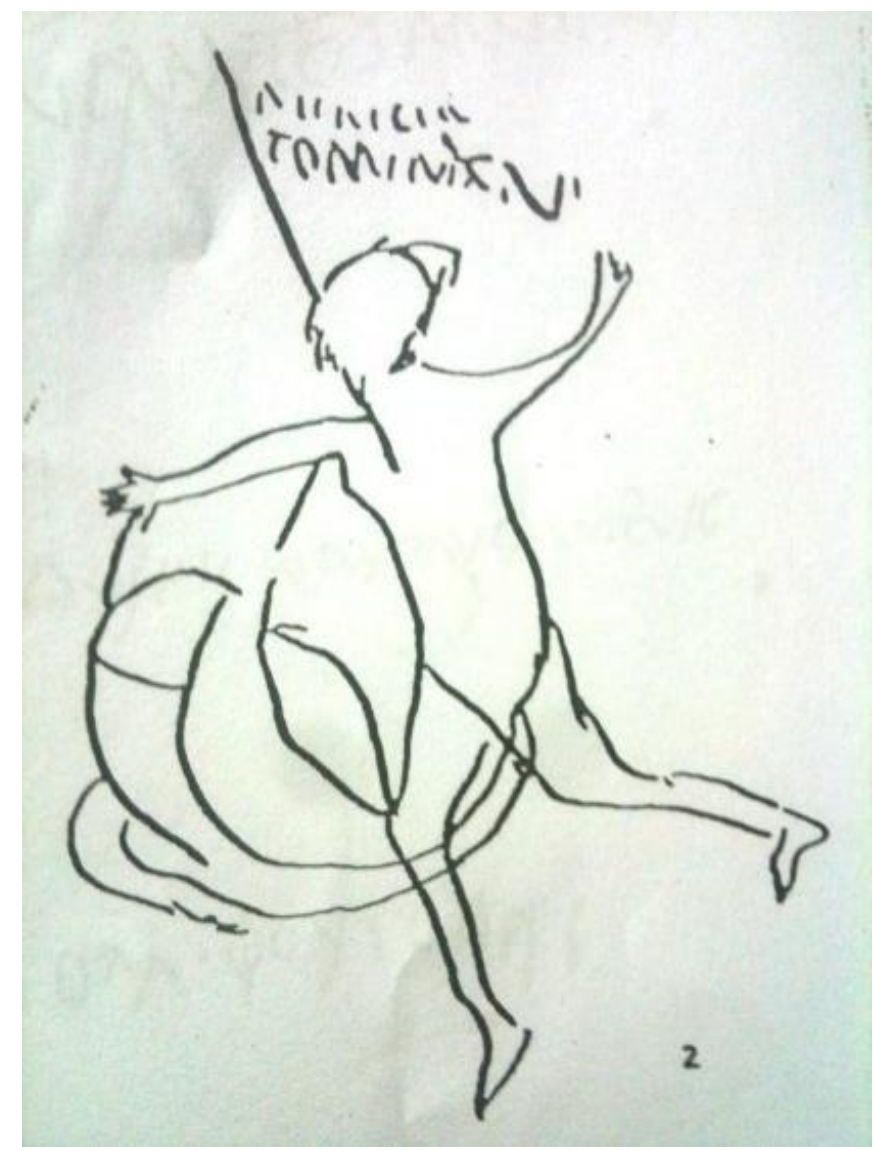

Figura 15. CIL IV, 4566. Fonte: (Funari, 1994: 7)

Para Funari (1994) este é um desenho itifálico, e está acompanhado de uma inscrição pouco clara: "felicio tominare", neste grafite, em sua opinião, a palavra tominare deve relacionar-se com tumeo (inchar) ou com torqueo (balançar), enquanto felicio deriva de felix, fértil e sortudo. Poderia ser, neste caso, interpretado como uma referência ao falo inchado ou balançando ${ }^{13}$. Lembrando que também é habitual na sociedade romana, utilizar uma cultura material que represente os testículos balançando em forma de sino (tintinnabulam), as campainhas nas entradas das casas em forma de falo, eram um forte talismã contra o mau agouro. Estes símbolos, de modo geral, ficavam em locais de transições, limen, "passagem do exterior para o interior, ligando o conhecido ao desconhecido; a representação fálica contribuía para afastar o perigo inerente a esta situação" (Funari, 2003: 321).

Por fim, vale também mencionar que a representação da própria cópula pode ser algo apotropaico, argumento reforçado por Catherine Johns (1990), que apresenta um paralelo imagético de um vaso de cerâmica gaulesa, de época

13 Encontramos também, representações alusivas ao falo em termas particulares, como é o caso da Casa do Menandro (I,10,4), cf. (Sanfelice, 2016, p.134). 
romana, no qual o homem coloca uma mulher em cima do altar ao ser penetrada. Para Johns, a cópula a partir dessa perspectiva, pode ser também explicada como algo sagrado, visto que está sendo simbolizada da mesma maneira que se referiam aos deuses, enaltecida num altar.

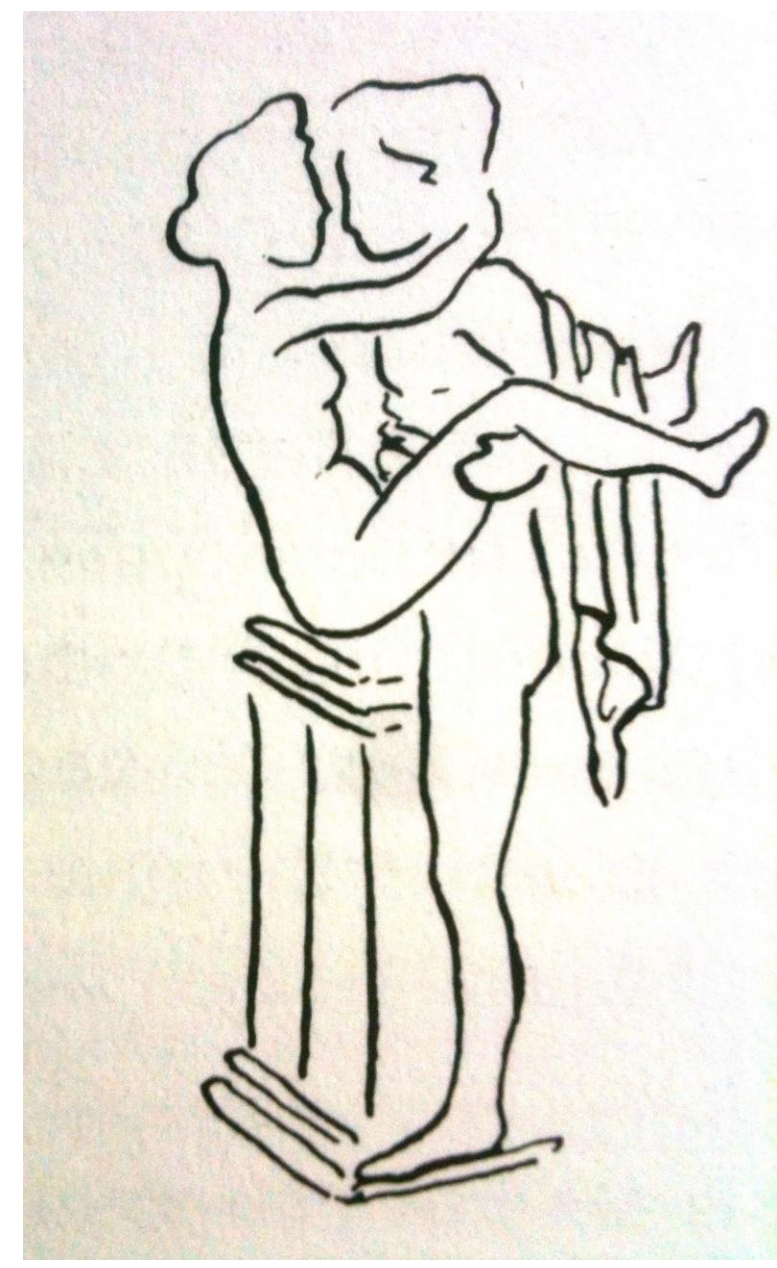

Figura 16. Mulher sentada no altar. Fonte: (Johns, 1990: 40)

As afirmações desta autora são importantes, porque de modo geral, valorizase nos estudos historiográficos o poder fálico, relacionado com o membro masculino, e quando se refere às expressões do ato sexual com uma mulher, surpreendentemente, não são associadas às conotações apotropaicas. Na cultura romana tem-se muitos artefatos que apresentam o falo em ereção, mas ao serem entendidos no âmbito da proteção e fruição da vida, podem ser pensados como uma referência a própria cópula e, de certa forma, englobaria o poder dos dois sexos para a potencialização da fertilidade (Adkins \&Adkins, 1996; Funari, 2003).

Diante das interpretações apresentadas, não pretendo afirmar que os povos da antiguidade não se sentiam estimulados a rir dos códigos sexuais-sociais 
desviantes, ou que não tinham prazer erótico, ou se se sentiam sexualmente estimulados por imagens como estas. O que proponho é a existência de múltiplas possibilidades interpretativas, sugiro um olhar mais plural para as leituras dos sistemas sexo-gênero no mundo antigo, que não precisam se resumir necessariamente a dois eixos (ativo-passivo), e também ressalto a possibilidade de outros significados para a representações das práticas sexuais nessa cultura.

Em suma, sugiro que as imagens trabalhadas nesta ocasião estão aquém das relações de gênero e da instabilidade destas relações, estas podem nos oferecer um significado simbólico muito importante para a compreensão das crenças do mundo antigo. Nesse sentido, acredito que há uma forte relação da representação da sexualidade com a vida cotidiana romana pompeiana - em um contexto em que as pessoas estavam muito expostas aos olhares, era comum que nos camarins de banhos públicos existissem algumas imagens de falos, figas, relações sexuais, pois havia uma crença que assim afastar-se-ia toda a energia ruim. Considerando-se que o sexo e as práticas sexuais eram um componente natural da vida, isto é, as referências explícitas à cópula poderiam ter uma conotação positiva, em alguns momentos foram entendidos como algo especial, com bom humor ou simplesmente como um presente muito apreciado pelos deuses, e não por acaso, há o uso de alguns símbolos relacionados a certas divindades (o peixe, os braceletes e o próprio cinturão vinculados à Vênus; o livro, liber, relacionado ao Liber Pater, Baco, também vinculado à fertilidade ${ }^{14}$ ). Pois como observou Jacobelli, no mundo antigo, havia um grande número de representações com conotações sexuais que era apotropaicas ou religiosas, o que criou um grau de familiaridade com imagens sexualmente explicitas, ainda que estranho para nossa cultura: "o sexo era visto como um componente normal e agradável da vida, e como tal, representado e vivido" (Jacobelli, 1995: 101).

\section{Considerações finais}

Nesse sentido, busquei evidenciar por meio de um debate historiográfico, que ainda há um discurso muito genérico a respeito da sexualidade romana, que tem como foco discutir e investigar práticas do gênero masculino ou os modelos de virilidade, ignorando a multiplicidade de práticas sexuais e de significados para estas relações. Diante disso, selecionei algumas pinturas eróticas pompeinas como um recurso para explorar novas possibilidades de relações e crenças entre os sujeitos da Antiguidade romana, e, sobretudo, para pensar o sistema sexo/gênero como uma categoria flexível, dentro de um

14 (cf. Sanfelice, 2016). 
campo de possibilidades que é reafirmado ou renegociado por meio de sucessivas "performances", como sugeriu Butler.

E para além destas questões mais epistemológicas, procurei propor também uma reflexão a respeito do nosso próprio cotidiano moderno, me inspirando no lema recuperado pelo professor Funari "E qual o motivo tão grande de visitares Roma? A Liberdade, que, embora tardia, (...)", por acreditar que o passado pode se tornar um local privilegiado de transformação social e da busca pela liberdade no nosso mundo contemporâneo. Portanto, observar as formas como os antigos lidaram com a sexualidade, com o corpo, com as representações estéticas, com os prazeres e crenças, é, sem dúvida, um modo de reconhecermos as múltiplas maneiras de se viver no mundo, e de encorajar possibilidades mais libertárias de existências e, principalmente, de coexistências.

\section{Agradecimentos}

Agradeço ao Pedro Paulo Funari por sua incansável e inspiradora luta por abordagens libertárias, interdisciplinares e críticas sobre o passado. Ao Glaydson José da Silva pelo convite e estímulo para publicar as reflexões aqui presentes. Agradeço à Renata Senna Garraffoni, e Lourdes Conde Feitosa pelas contribuições e valorosos ensinamentos a respeito dos estudos de gênero. Ao estimado Guilherme Gontijo Flores pelos diálogos e referenciais clássicos que certamente enriqueceram as leituras das imagens aqui trabalhadas. Institucionalmente cabe destacar o Programa de Pós-graduação e ao Departamento de História da UFPR, além da Capes que me concedeu a bolsa de estudos para que eu pudesse realizar meu doutorado e pesquisar o sítio arqueológico de Pompeia. A responsabilidade das ideias recai apenas sobre a autora.

\section{Fontes antigas}

APULEYO. (1978). El Asno de Oro. (L. R. Fernandez, Trad.) Madrid: Editorial Gredos.

OVIDIO. (1989). Amores o Arte de Amar. (V. C. López, Trad.) Madrid: Ediorial Gredos.

\section{Referências bibliográficas}

ADKINS, L., \& ADKINS, R. A. (1996). Dictionary of Roman Religion. New York: Oxford University Press. 
BERNAL, M. (2005). A Imagem da Grécia Antiga como uma ferramenta para o colonialismo e para a hegemonia européia. Em P. P. Funari, Repensando o Mundo Antigo. Coleção Textos Didáticos n4 49. Campinas: IFCH-UNICAMP.

BUTLER, J. (2000). Corpos que pesam: sobre os limites discursivos do 'sexo'. Em G. L. Louro, O Corpo Educado - Pedagogias da Sexualidade. Belo Horizonte: Autêntica.

BUTLER, J. (2010). Problemas de Gênero: feminismo e subversão da identidade. Rio de Janeiro: Civilização Brasileira.

CLARKE, J. (2001). Looking at Lovemaking: Constructions of Sexuality in Roman Art 100B.C. - A.D. 250. California: University of California Press.

CLARKE, J. (2003). Roman Sex: 100 B.C. to A.D. 250. New York: Harry N. Abrams Inc. Publishers.

CLARKE, J. (2007). Looking at Laughter: Humor, Power and Trangression in Roman Visual Culture 100 B.C.- A.D. 250. Los Angeles: University of California Press.

CLARKE, J. (2007). Roman Life 100 B.C. to A.D. 200. New York: Harry N. Abrams Inc. Publishers.

DÍAZ-ANDREU, M. (2002). Cultura y Nación: Una Mirada Historiográfica. Historia de la Arqueología.Estudios.Madrid, Ediciones Clásicas, 153-164.

FEITOSA, L. (2003). Gênero e o "Erótico" em Pompeia. Em P. P. FUNARI, L. C. FEITOSA, \& G. J. SILVA, Amor, Desejo e Poder na Antiguidade: Relações de Gênero e Representações do Feminino (pp. 297-316). Campinas: Editora da Unicamp.

FEITOSA, L. C. (2005). Amor e Sexualidade: o Masculino e o Feminino em grafites de Pompeia. São Paulo: Annablume.

FEITOSA, L. C. (2014). O amor entre iguais: o universo masculino na sociedade romana. Em A. ESTEVES, K. T. AZEVEDO, \& F. FROWHWEIN, Homoerotismo na Antiguidade Clássica (pp. 137-154). Rio de Janeiro: UFRJ.

FEITOSA, L. C., \& RAGO, M. (2008). Somos tão antigos quanto modernos? Sexualidade e gênero na Antiguidade e na modernidade. Em \&. P. M. RAGO, Subjetividades antigas e moderna. São Paulo: Anablumme.

FEITOSA, L. C., \& RAGO, M. (2008). Somos tão antigos quanto modernos? Sexualidade e gênero na Antiguidade e na modernidade. Em M. RAGO, \& P. P. FUNARI, Subjetividades antigas e modernas. São Paulo: Anablumme. 
FLORES, G. G. (2017). Que cada um cante seu amor. Em R. Carvalho, G. G. FLORES, M. M. GOUVÊA JUNIOR, \& J. A. OLIVA NETO, Por que calar nossos amores?: Poesia homoerótica latina (pp. 13-23). Belo Horizonte: Autêntica Editora.

FOUCAULT, M. (1997). Arqueologia do Saber. Rio de Janeiro: Forense Universitária.

FOUCAULT, M. (2006). A Ordem do Discurso. São Paulo: Edições Loyola.

FOUCAULT, M. (2009a). História da Sexualidade I: A Vontade de Saber. Rio de Janeiro: Graal.

FOUCAULT, M. (2009b). História da Sexualidade II: O Uso dos Prazeres. São Paulo: Edições Graal.

FOUCAULT, M. (2007). Historia da Sexualidade III: O Cuidado de Si. Rio de Janeiro: Graal.

FUNARI, P. P. (1994). As inscrições populares pompeianas e seu caráter apotropaico. Artigo apresentado, originalmente, no Grupo de Trabalho "Os sentidos do Apotropaico", no Museu de Arqueologia e Etnologia da Universidade de São Paulo.

FUNARI, P. P. (2003). Falos e Relações Sexuais: Representações Romanas para além da Natureza. Em P. P. FUNARI, L. C. FEITOSA, \& G. J. SILVA, Amor, Desejo e Poder na Antiguidade: Relações de Gênero e Representações do Feminino (pp. 317-325). Campinas- São Paulo: Editora UNICAMP.

FUNARI, P. P. (2004). A importância de uma abordagem crítica da História Antiga nos livros escolares. REVISTA HISTÓRIA HOJE, SÃO PAULO, N 4.

FUNARI, P. P. (2014). Prefácio: um tema inovador. In: A. M. ESTEVES, K. T. AZEVEDO, \& F. FROHWEIN, Homoerotismo na Antiguidade Clássica (pp. 1720). Rio de Janeiro: UFRJ.

FUNARI, P., \& RAGO, M. (2008). Apresentação. In: M. (. Rago, \& F. P. (Org)., Subjetividades antigas e modernas (pp. 09-12). São Paulo: Anablumme.

GARRAFFONI, R. S., \& FUNARI, P. (2004). História Antiga na sala de aula. Campinas: IFCH/UNICAMP.

GARRAFFONI, R. S., \& SANFELICE, P. (2017). Escavando Pompeia no início do século XX: arqueologia, nascionalismo e identidades em conflito. Em G. SILVA, R. GARRAFFONI, P. FUNARI, J. GRALHA, \& R. RUFINO, 
Antiguidade como presença: antigos, modernos e os usos do passado (pp. 269-296). Curitiba: Editora Prismas.

GARRAFFONI, R. S., \& SANFELICE, P. d. (2014). Homoerotismo nas paredes de Pompeia. Em A. M. ESTEVES, K. T. AZEVEDO, \& F. FROHWEIN, Homoerotismo na Antiguidade Clássica (pp. 219-248). Rio de Janeiro: UFRJFaculdade de Letras.

HALPERIN, D. M. (1990). One Hundred Years of Homosexuality: and Others essays on Greek. New York: Routledge.

HINGLEY, R. (2002). Concepções de Roma: uma perspectiva inglesa. Em P. P. Funari, Repensando o Mundo Antigo. Coleção Textos Didáticos nº 47. Campinas: IFCH-UNICAMP.

HINGLEY, R. (2005). Globalizing Roman Culture - Unity, diversity and Empire. London: Routledge.

HINGLEY, R. (2010). O imperrialismo romano: novas perspectivas a partir da Bretanha. São Paulo: Annablume.

HOLMES, B. (2012). Gender - Antiquity ans Its Legacy. New York: Oxford University Press.

JACOBELLI, L. (1995). Le pitture erotiche delle Terme Suburbane di Pompei. Roma: L'Erma.

JOHNS, C. (1990). Sex or Symbol- Erotic Images of Greece and Rome. Austin: University of Texas Press.

LAURENCE, R. (1996). Roman Pompeii: Space and Society. London: Routledge.

LAURENCE, R. (2010). Roman Passions. London: Continuum.

LAURETIS, T. (1994). A técnologia de Gênero. Em E. B. HOLANDA, Tendência e Impasses: O Feminismo como Crítica da Cultura (pp. 206-242). Rio de Janeiro: Rocco.

PARKER, H. N. (1992). Love's Body Anatomized: The Ancient Eroti Handbook and the retoric of Sexuality. Em A. Richlin, Pornography and Representation in Greece and Rome (pp. 90-111). Oxford: Oxford.

PINTO, R. (2011). Representações homoeróticas masculinas na cultura material romana e as exposições dos museus:o caso da Warren Cup. MÉTIS: história \& cultura - v. 10, n. 20,111-132. 
POMEROY, S. (1995). Goddesses, Whores, Wives, and Slaves: Women in Classical Antiquity. New York: Schocken Books.

RAGO, M. (2002). Libertar a História. Em M. RAGO, L. L. ORLANDI, \& A. VEIGA-NETO, Imagens de Foucault e Deleuze - Ressonâncias Nietzschianas (pp. 256-272). Rio de Janeiro: DP\&A Editora.

RICHLIN, A. (1993). Not before Homosexuality: The Materiality of the Cinaedus and the Roman Law Against Love bethween men. History of Sexuality 3, 523-63.

SANFELICE, P. P. (2016). Sob as cinzas do vulcão: representações da religiosidade e da sexualidade na cultura material de Pompeia durante o Império romano. . Curitiba: Tese de Doutorado em História - Universidade Federal do Paraná. 2016.

SANFELICE, P. P. (2012). Amor e Sexualidade em Ruinas: As Pinturas da Deusa Vênus nas Paredes de Colonia Cornelia Veneria Pompeianorum. Curitiba: Dissertação (Mestrado em História) - Setor de Ciências Humanas, Letras e Artes, Universidade Federal do Paraná.

SANFELICE, P. P. (2013). A Arte do Corpo: Incorporando a sexualdiade Masculinas e Feminina na Cultura Material de Pompeia. Revista Memorare, $v$. 1,Unisul, 1-16.

SCOTT, J. W. (1995). Gênero: uma categoria útil de análise histórica. Educação $\mathcal{E}$ Realidade vol. 20, $n^{\circ}$ 2, 71-99.

SILVA, G. J. (2007). História Antiga e usos do passado: um estudo de apropriações da Antiguidade sob o regime de Vichy (1940/44). São Paulo: Annablume/Fapesp.

SILVA, G. J., GARRAFFONI, R., FUNARI, P., GRALHA, J., \& RUFINO, R. (2017). Antiguidade como presença: antigos e modernos e os usos do passado. Curitiba: Editora Prismas.

SKINNER, M. (1997). Introduction. Em J. HALLET, \& M. SKINNER, Roman Sexualities (pp. 3-25). New Jersey: Princeton.

SKINNER, M. B. (1996). Zeus and Leda: The Sexuality Wars in Contemporary Classical Scholarship. Thamyris 3, 103-23.

TERRANATO, N. (2001). Ancestor cults: the perception of Rome in modern Italian culture. Em R. Hingley, Images of Rome: Perceptions of ancient Rome in Europe and United States in the modern age (pp. 71-89). Rhode Island. 
VARONE, A. (2002). Erotica Pompeiana: Love Inscriptions on the Walls of Pompeii. Roma: L'Erma di Bretschneider.

VEYNE, P. (2009). História da Vida Privada: do Império Romano ao Ano Mil. São Paulo: Companhia das Letras.

VOSS, B. (2012). Sexual Effects: Postcolonial and Queer Perspectives on Archaeology of Sexuality and Empire . Em B. VOSS, \& E. CASELLA, The Archaeology of Colonialism: Intimate Encouters and Sexual Effects. New York: Cambridge University Press.

WALTERS, J. (1997). Invading the Roman Body: Manliness and impenetrability in Roman thought. Em Judith Hallet and Marilyn Skinner; Roman Sexuality (pp. 29-43). Princeton: Princeton University Press.

WINKLER, J. J. (1990). The Constraints of Desire: The Anthropology of Sex and Gender in Ancient Greece. New York: Routledge. 